\title{
PROTEROTHERIIDAE AND MACRAUCHENIIDAE (LITOPTERNA, MAMMALIA) FROM THE PLEISTOCENE OF RIO GRANDE DO SUL STATE, BRAZIL
}

\author{
CAROLINA SALDANHA SCHERER, VANESSA GREGIS PITANA \& ANA MARIA RIBEIRO \\ Seção de Paleontologia, Museu de Ciências Naturais, Fundação Zoobotânica do Rio Grande do Sul, Av. Salvador França, \\ 1427, 90690-000, Porto Alegre, RS, Brasil \\ carolina_scherer@yahoo.com.br,gregisva@gmail.com,ana.ribeiro@fzb.rs.gov.br
}

\begin{abstract}
New materials of the order Litopterna from the late Pleistocene (Lujanian) of Rio Grande do Sul State are presented here. The specimens are an astragalus and calcaneum, assigned to cf. Neolicaphrium recens, and fragments of mandible, humeri, tibia and fibula, astragali, besides vertebrae and metatarsal, all of them attributed to Macrauchenia patachonica. The material described here comes from the municipalities of Santa Vitória do Palmar (Hermenegildo Beach, Chuí Creek), Uruguaiana (Touro Passo Creek), Alegrete (Sanga da Cruz Creek) and Pantano Grande (Sanga Borba Creek). The record of these taxa in the Lujanian of Rio Grande do Sul State shows a greater similarity with the fauna in the same latitudinal belt of Argentina and Uruguay than that of the intertropical region.
\end{abstract}

Key words: Litopterna, Proterotheriidae, Macraucheniidae, Lujanian, Rio Grande do Sul State.

RESUMO - São aqui apresentados novos materiais da Ordem Litopterna para o Pleistoceno final (Lujanense) do Estado do Rio Grande do Sul. Os espécimes constam de astrágalo e calcâneo, atribuídos a cf. Neolicaphrium recens; e fragmentos de mandíbula, úmeros, tíbia e fíbula, astrágalos, além de vértebras e metatarsal, todos atribuídos a Macrauchenia patachonica. O material aqui descrito provém dos municípios de Santa Vitória do Palmar (Balneário Hermenegildo e Arroio Chuí), Uruguaiana (Arroio Touro Passo), Alegrete (Sanga da Cruz) e Pantano Grande (Sanga Borba). O registro destes táxons para o Lujanense do RS evidencia, mais uma vez, a maior similaridade da fauna deste estado com a da mesma faixa latitudinal da Argentina e do Uruguai, do que com a da região intertropical.

Palavras-chave: Litopterna, Proterotheriidae, Macraucheniidae, Lujanense, Rio Grande do Sul.

\section{INTRODUCTION}

The Litopterna Ameghino, 1889 are native ungulates of South America that had a wide distribution on this continent since the late Paleocene until the late Pleistocene. The order Litopterna (sensu McKenna \& Bell, 1997) includes the families Protolipternidae Cifelli, 1983 (late Paleocene), Notonychopidae Soria, 1989 (late Paleocene), Adianthidae Ameghino, 1891 (early Eocene - middle Miocene), Proterotheriidae Ameghino, 1887 (late Paleocene - late Pleistocene) and Macraucheniidae Gervais, 1855 (late Paleocene - late Pleistocene), the last two being the main goal of this work.

The Proterotheriidae include two subfamilies and 18 genera (sensu McKenna \& Bell, 1997), of small and middle size forms. They are characterized mainly by brachydont to mesodont dentition and a marked trend toward monodactily, with digit III more developed, digits I and V lost, and digits II and IV reduced (Bond, 1999; Bond et al., 2001). They are recorded for the Tertiary in Argentina, Brazil, Bolivia, Chile, Colombia and Uruguay (Marshall et al., 1983; Frailey, 1986; Bond et al., 1995; Bergqvist, 1996; Cifelli \& Guerrero, 1997;
Bergqvist et al., 1998; Bond, 1999; Flynn et al., 2002; Kramarz $\&$ Bond, 2005). Since the Mio-Pliocene, their diversity was reduced and they were considered extinct in the late Pliocene (Bond, 1999). However, Neolicaphrium recens Frenguelli, 1921 was described for the Lujanian (late Pleistocene, Cione \& Tonni, 2005, including Bonaerian, sensu Bond et al., 2001) of Argentina (Cordoba Province), and further, finds of this species were recorded for the Lujanian (including Bonaerian) of Uruguay (Salto Department) and Argentina (Cordoba, Corrientes and Santa Fe Provinces) and also for the Ensenadan (early to middle Pleistocene, Cione \& Tonni, 2005) (Córdoba Province, Argentina) (Alvarez, 1974; Perea et al., 1998; Tauber, 2000; Bond et al., 2001; Ubilla et al., 2007; Vezzosi et al., 2009). Pitana et al. (2005) reported the presence of an undetermined Proterotheriidae material for the Lujanian of southern Brazil (Figure 1).

The family Macraucheniidae includes three subfamilies and 16 genera of middle size to very large forms. The representatives of this family are more conservative in dental and postcranial aspects than proterotherids, and are characterized mainly by the retraction of the nasals and the 
backward shift of the narines and by complete dental formula (Bond, 1999). They are recorded for the Tertiary of Argentina, Brazil, Bolivia, Colombia and Chile (Marshall et al., 1983; Perea et al., 1994; Bond et al., 1995; Cifelli \& Guerrero, 1997; Bond, 1999; Flynn et al., 2002; Croft et al., 2004, 2007). For the Pleistocene of the Buenos Aires Province (Argentina), Ameghino (1888) described Macrauchenia ensenadensis, later transferred to the genus Macraucheniopsis by PaulaCouto (1945). Currently, this species is considered as valid for the Ensenadan of the Pampean region of Argentina (Bond, 1999). Macrauchenia patachonica Owen, 1838 is recorded since the Ensenadan, by only one find for the Pampean region of Argentina (Bond, 1999), and more abundantly for the Lujanian (including the Bonaerian) of Argentina, in the Pampean (Buenos Aires, Santa Fe and San Luis Provinces), Mesopotamian (Corrientes and Entre Rios Provinces), Patagonian (Santa Cruz Province) and northern regions (Formosa and Jujuy Provinces) (Ameghino, 1889; Bond, 1999; Ferrero et al., 2007; Ferrero, 2009). This species was also recorded for the Lujanian of southern Brazil, Uruguay,

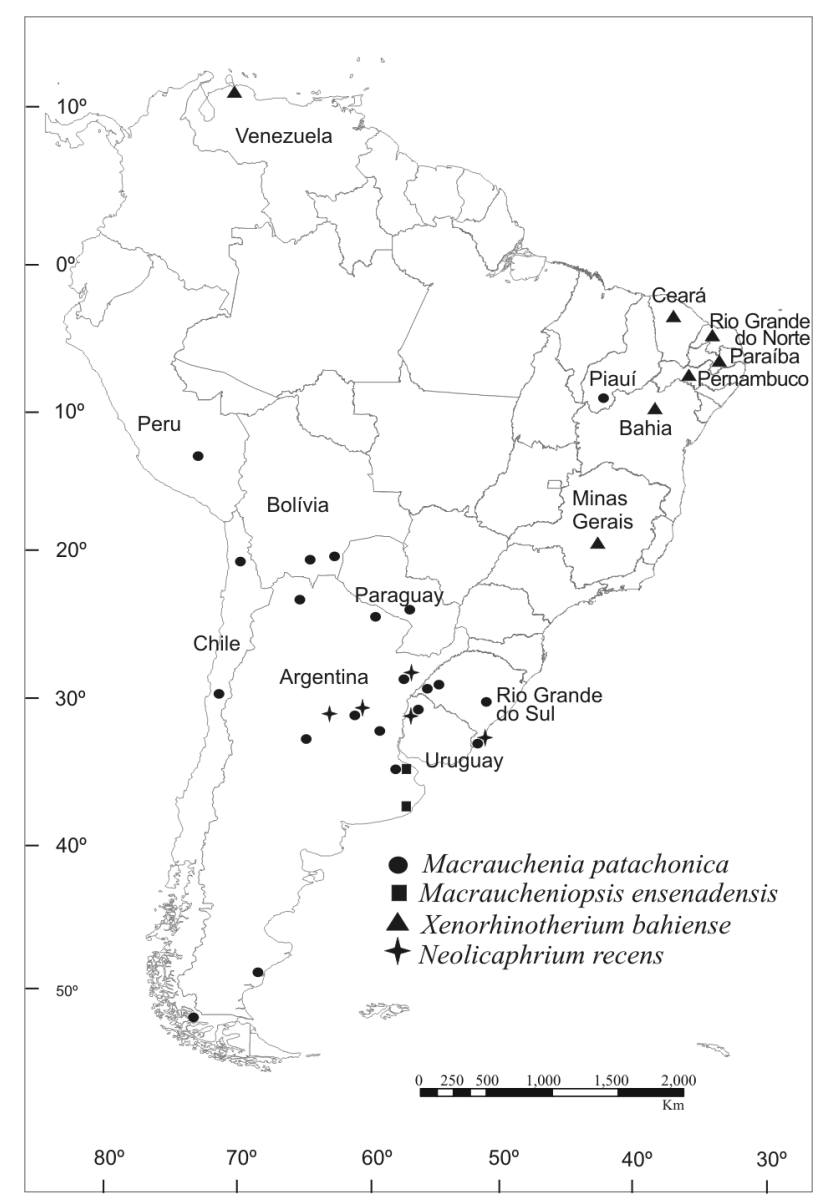

Figure 1. Geographic distribution of the Macraucheniidae and Proterotheriidae during the Pleistocene in South America, according to Paula-Couto (1945), Alvarez (1974), Marshall et al. (1984), Cartelle \& Lessa (1988), Oliveira et al., (1989), Bergqvist (1993), Bergqvist et al. (1997), MacFadden \& Shockey (1997), Perea et al. (1998), Bond (1999), Casamiquela (1999), Tauber (2000), Bond et al. (2001), Guérin \& Faure (2004), Ubilla (2004), López \& Labarca (2005), Scherer et al. (2006), Coltorti et al. (2007), Ubilla et al. (2007), Socorro (2006), and Vezzosi et al. (2009).
Paraguay, northern and southern Chile, Peru and Bolivia (from the Nuapua and Tarija faunas, where deposits are assigned to Ensenadan or Lujanian, according to different authors) (Souza-Cunha, 1959; Marshall et al., 1984; Marshall \& Sempere, 1991; Oliveira, 1992; Buchmann, 1994; Ubilla et al., 1994; MacFadden \& Shockey, 1997; Bond, 1999; Casamiquela, 1999; Ubilla, 2004; López \& Labarca, 2005; Scherer et al., 2006; Coltorti et al., 2007). Macrauchenia patachonica was recorded for the northeastern Brazilian states of Pernambuco, Bahia, Ceará, Paraíba and Minas Gerais (e.g., Winge, 1906; Paula-Couto, 1947, 1954, 1970, 1980; Vidal, 1946, 1955). Xenorhinotherium bahiense Cartelle \& Lessa, 1988 was described based on material from states of Bahia (northeastern Brazil) and Minas Gerais (southeastern Brazil). These authors suggested that all the Macraucheniidae material previously recorded from the northeastern Brazil should belong to this taxon. Later records of macraucheniids from states of Bahia, Pernambuco, Ceará, Paraíba and Rio Grande do Norte were also assigned to X. bahiense (Oliveira et al., 1989; Bergqvist, 1993; Bergqvist et al., 1997). Recently, Guérin \& Faure (2004) suggested that this taxon could be a synonym of Macrauchenia patachonica, including new material from Piauí State. Nevertheless, some authors (e.g., Socorro, 2006) do not follow this proposition, considering $X$. bahiense as a valid taxon. Xenorhinotherium bahiense was also recently recorded for the Muaco, Taima Taima and Cuenca del Lago de Valencia faunas from Venezuela (Socorro, 2006). Recently, Dias-Neto et al. (2008) referred to the presence of the Macraucheniidae in the Pleistocene of Alagoas State, but these authors did not assign the material to Macrauchenia or Xenorhinotherium due to the absence of diagnostic elements. For Rio Grande do Sul State, Macrauchenia patachonica has been recorded for the Coastal Plain of Rio Grande do Sul, by Souza-Cunha (1959), for Sanga da Cruz Creek (Alegrete) by Oliveira (1992), Lessa \& Oliveira (1996), Milder (2000) and Scherer \& Da-Rosa (2003), and for the Pantano Grande Municipality by Scherer et al. (2003). Scherer et al. (2006) revised the material of the Macraucheniidae from this state and referred the material from the municipalities of Santa Vitória do Palmar (Hermenegildo Beach), Uruguaiana (Touro Passo Creek) and Alegrete (Sanga da Cruz Creek) to Macrauchenia patachonica (Figure 1).

This work provides a description and comparison of fossil remains of Macraucheniidae and Protherotheriidae from Pleistocene of Rio Grande do Sul State, and includes a discussion about the taxonomic relevance of its osteological and dental features.

\section{GEOLOGICAL SETTING}

The material of Litopterna from Rio Grande do Sul State comes from Pleistocene fluvial and lagoonal deposits, from the municipalities of Uruguaiana (Touro Passo Creek), Alegrete (Sanga da Cruz Creek), Pantano Grande (Sanga Borba Creek) and Santa Vitória do Palmar (Hermenegildo Beach and Chuí Creek).

Touro Passo Creek is a tributary on the left bank of the 
Uruguay River and is situated $13 \mathrm{~km}$ north of Uruguaiana City, and its best studied area is at $29^{\circ} 40^{\prime} \mathrm{S}$ and $56^{\circ} 50^{\prime} \mathrm{W}$ (Bombin, 1976) (Figure 2A). In this creek, Bombin (1976) defined the Touro Passo Formation, composed of a conglomeratic member, characterized by conglomerates that could represent channel deposits, overlapped by a muddy member, characterized by mudstone with sandy lenses and $\mathrm{CaCO}_{3}$ levels (rhizoconcretions), deposited in the floodplain. The material from Touro Passo Creek does not include details about the locality and level of collection, but according to the preservation, it is possible to infer that it comes from the carbonatic level (middle portion of muddy member) (Figure 2B). Bombin (1976) presented an absolute age of about 11,010 \pm 190 years BP (Before Present) $\left({ }^{14} \mathrm{C}\right)$ for a carbonized wood sample collected at the base of the muddy member. Milder (2000) did not regard the members of Bombin (1976) as formally proposed and called them conglomeratic and muddy facies. Oliveira \& Lavina (2000) proposed that the members of Bombin (1976) should be just local episodes of sedimentation. Milder (2000) performed thermoluminescence dating for the middle portion of the muddy facies, resulting in $15,400 \pm 750$ years BP and 16,327 \pm 800 years BP (Figure 2B), and Kotzian et al. (2005) carried out radiocarbon dating based on mollusks found at the same level, resulting in 15,970 \pm 90 years BP and 16,650 \pm 203 years BP.

Sanga da Cruz Creek is a drainage of Ibicuí River, situated

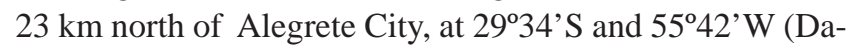
Rosa, 2003; Scherer \& Da-Rosa, 2003) (Figure 2A). At some points of this creek, called Salatiel II, there is the same kind of lithology as found in Touro Passo Creek, with a lower conglomeratic level and an upper muddy level, but in such deposits the strata are thinner. The fossils, including those studied here, are found in the conglomeratic level, incomplete and isolated, suggesting a post-fossilization reworking and with cementation with ferrous material (Scherer \& Da-Rosa, 2003). For these levels, thermoluminescence dating indicated about $14,925 \pm 800$ and $14,830 \pm 750$ years $\mathrm{BP}$ at the lower level, associated with mammal fossils, and 13,880 \pm 800 and $11,740 \pm 600$ years BP for the upper muddy facies (Milder, 2000, Da-Rosa, 2003) (Figure 2C). Oliveira (1992) accepted the ages of $17,830 \pm 100$ and $17,850 \pm 190$ years BP reported by Miller (1987) for these fossil-bearing deposits (including the material studied here), but these ages were determined from carbonized wood collected at another lower level of the Ibicuí River (Ribeiro \& Scherer, in press). At another location of Sanga da Cruz Creek, next to the mouth of the Ibicuí River, there are only muddy deposits, with some levels differentiated by the presence of carbonate concretions, like those found in Touro Passo Creek, although there is none found of Litopterna in these deposits. Miller (1987) performed ${ }^{14} \mathrm{C}$ dating that resulted in $12,770 \pm 220$ years BP for these last deposits based on a skull of Glossotherium.

Sanga Borba Creek is located about $3 \mathrm{~km}$ north of Pantano Grande City, at $30^{\circ} 09^{\prime} \mathrm{S}$ and $52^{\circ} 05^{\prime} \mathrm{W}$ (Scherer et al., 2002, 2003) (Figure 2A). The deposits are composed of white mudstones partially exposed, eroded, and overlapped by a conglomerate with a muddy matrix, which constitute the floor of the drainage and contain the disarticulated and fragmented fossil material, suggesting reworking. This lithology represents an alluvial deposition, characterized by a fluvial facies at the base of the deposition, and slip processes on top (Átila da Rosa, personal communication). At the moment, there is no absolute dating for these deposits, but the presence of Equus (Amerhippus) neogaeus fossils suggest a Lujanian age (Ribeiro \& Scherer, in press).

The Coastal Plain of Rio Grande do Sul had its origin related to the opening of the Atlantic Ocean in the early Cretaceous, and has been modified with sea level fluctuations. The current landscape was developed through lateral juxtaposition of a depositional system of alluvial fans and four lagoon-barrier systems formed by transgressiveregressive events; systems I, II and III are Pleistocene in age, while system IV is Holocene (Villwock \& Tomazelli, 1995) (Figure 2E). The material studied here was collected along the shoreline of the Hermenegildo Beach (Figures 2D) and in Chuí Creek, both of them in the Santa Vitória do Palmar Municipality (Figure 2A). These fossils are associated with the deposits of Lagoon-Barrier System III, which have an estimated age of about 120,000 years BP (Villwock \& Tomazelli, 1995). The Chuí Creek material was collected in situ in layers exposed near the ridge between Santa Vitória do Palmar City and Hermenegildo Beach $\left(33^{\circ} 35^{\prime} 26,39^{\prime \prime} S\right.$ and $53^{\circ} 20^{\prime} 22,11^{\prime \prime} \mathrm{W}$ ) (Lopes et al., 2005). The deposits along this creek show beach facies at the base, characterized by middlegrained sandstone, overlapped by a thick layer of muddy sandstone, probably fluvial or lagoonal in its origin, where there are the mammal fossils (Lopes et al., 2005). There is no absolute dating for this fossiliferous level, but the assemblage permits a Lujanian age to be inferred (Oliveira et al., 2005; Lopes et al., 2005). The fossils collected in Chuí Creek are well preserved and sometimes articulated, but can also be found to be fractured and disarticulated (like the specimen MCN-PV 3155), suggesting little transport (Lopes et al., 2001). According to Lopes et al. (2001), the fossils collected on Hermenegildo Beach should be originally deposited in lagoonal facies (like those of Chuí Creek), and then reworked and cemented with calcium carbonate in a marine shore environment and preserved in parcels and submerged banks (foreshore and continental platform) along the coast of Rio Grande do Sul State. The fossil material comes from several source-areas, such as the Hermenegildo parcel, and presently these deposits have been eroded and transported due to the action of present hydrodynamic processes, until the coastline, where they are found rolled (Buchmann, 1994; Buchmann, 2002).

\section{MATERIAL AND METHODS}

The studied material consists of mandibular and postcranial elements deposited in the Paleovertebrates 

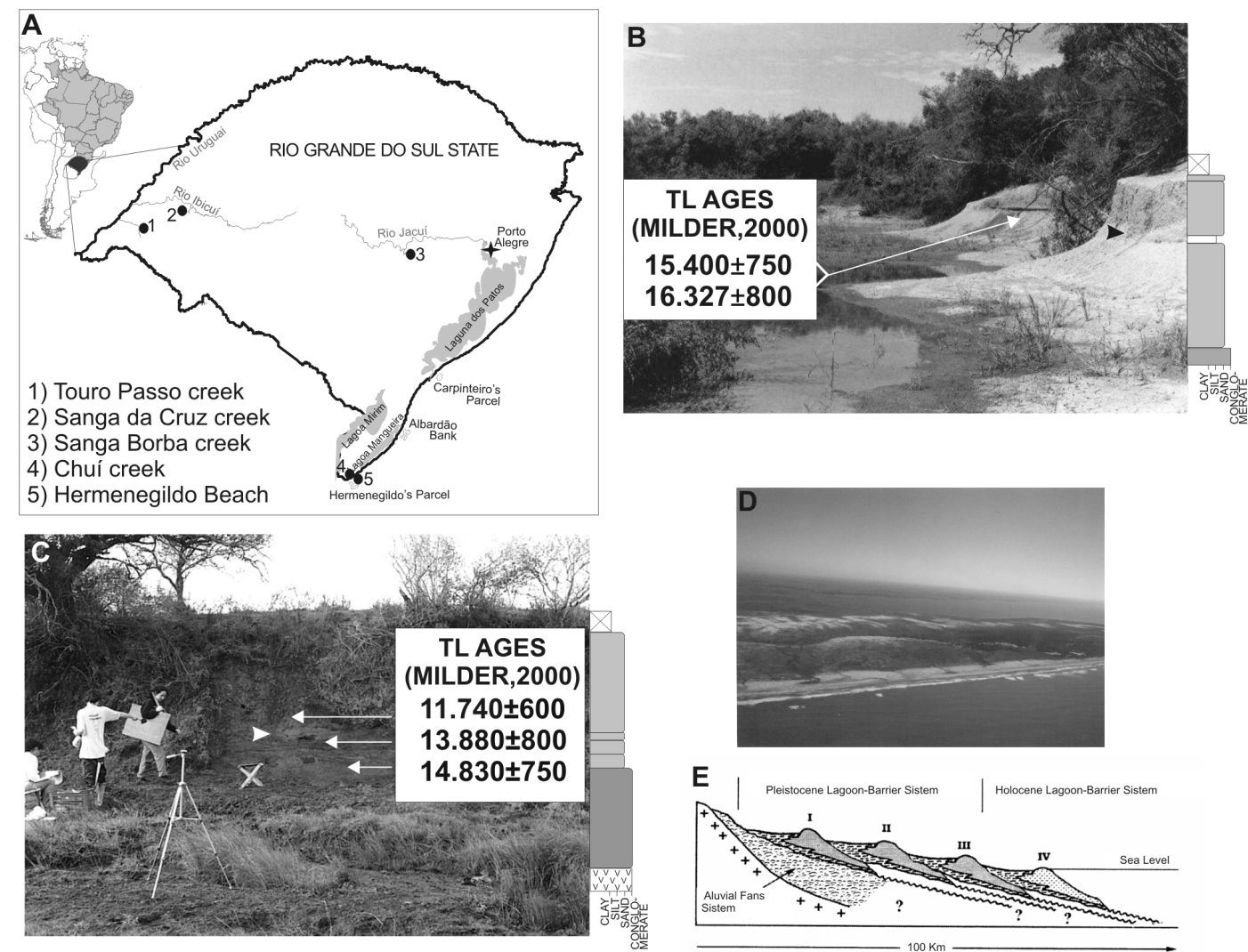

Figure 2. A, Location of outcrops where the Litopterna fossils were found in Rio Grande do Sul State; B, Touro Passo Creek, stratigraphic profile and datings (from Da-Rosa, 2003); C, Sanga da Cruz Creek, stratigraphic profile and datings (from Da-Rosa, 2003); D, general view of Hermenegildo Beach (from Francisco Buchmann); E, profile of deposits of Coastal Plain of Rio Grande do Sul State (from Tomazelli \& Villwock, 2000).

Collection of Museu de Ciências Naturais of the Fundação Zoobotânica do Rio Grande do Sul and Laboratório de Estratigrafia e Paleobiologia of the Universidade Federal de Santa Maria.

The bony terminology follows Sisson \& Grossman (1963) and Schaller (1992), whenever possible. The dental terminology follows Cartelle \& Lessa (1988). The systematics follows Cartelle \& Lessa (1988), for the Macraucheniidae, and Bond et al. (2001) and Soria (2001) for the Proterotheriidae. Abbreviations. AMNH, American Museum of Natural History, New York; DGM, Divisão de Geologia e Mineralogia do Departamento Nacional de Produção Mineral, Rio de Janeiro; FUMDHAM, Fundação Museu do Homem Americano, São Raimundo Nonato; MACN Pv, Museo Argentino de Ciencias Naturales "Bernardino Rivadavia", Buenos Aires; MCL, Museu de Ciências Naturais of Pontifícia Universidade Católica de Minas Gerais, Belo Horizonte; MCNPV, Museu de Ciências Naturais of Fundação Zoobotânica do Rio Grande do Sul, Paleovertebrates Collection, Porto Alegre; MGGC, Museo Municipal de Ciencias Naturales Guillermo Gómez Cadret, San Jose; MNRJ, Museu Nacional do Rio de Janeiro, Rio de Janeiro; MLP, Museo de La Plata, La Plata; TAR, Collection Tarija, Muséum National d’Histoire Naturelle, Paris; UFSM, Laboratório de Estratigrafia e Paleobiologia, Universidade Federal de Santa Maria.

\section{SYSTEMATIC PALEONTOLOGY}

Order LITOPTERNAAmeghino, 1889

Suborder LOPHOLIPTERNA Cifelli, 1983

Superfamily PROTEROTHERIOIDEA Ameghino, 1887

Family PROTEROTHERIIDAE Ameghino, 1887

Subfamily PROTEROTHERIINAE Ameghino, 1887

cf. Neolicaphrium recens Frenguelli, 1921

(Figures 3A, D, Tables 1-2)

Material. MCN-PV 6976, left astragalus; MCN-PV 8948, left calcaneum.

Geographical provenance. Hermenegildo Beach (Santa Vitória do Palmar).

Description. The specimen MCN-PV 6976 (Figure 3A) has an elongated and slightly narrow morphology; its trochlea is pulley-shaped with strong vertical crests roughly parallel to the astragalar body. The lateral crest is greater than the medial one; the neck is short and shows a very concave fossa at the base of the neck, located on the dorsal face, which supports the anterior process of the tibia distal end. The head is convex with a medial expansion, formed exclusively by the navicular facet, which extends over the dorsal and plantar surfaces of the neck, which permits an increase in flexion and extension movements. Continuous to this facet, the sustentacular facet is narrowed and slightly convex. The ectal facet is very 
concave and deep, forming a large contact with the calcaneum. Proximolaterally, there is a flat fibular facet, and, proximomedially, the maleolar facet is characterized by a slightly concave area continuous with the distal surface.

The calcaneum MCN-PV 8948 (Figure 3D) has an elongated general morphology with the distal articular portion broader than the body, which is lateromedially flat and dorsoplantarly thick, uniformly narrow and thick in all its extension; there is no differentiated neck. The tuberosity is broken, but it seems to be slightly broader and thicker than the calcaneal body. The ectal facet is convex and oblique, posteriorly and medially extended over the calcaneal body. The fibular facet was not observed, probably due to poor preservation. The dorsally directed sustentacular facet is wide and oval-shaped with greater anteroposterior diameter extending it until the cuboidal facet margin. A prominent crest extends from the ectal facet until the cuboid's facet. The region between this crest and the sustentacular facet is very concave and rugose, possibly related to ligament insertion. The dorsal portion of the cuboid facet is triangular, slightly concave and medially turned, while the plantar portion of this facet is lacking.

Discussion. The studied material by its morphology is referred to the litoptern Proterotheriidae and was compared with the proterotheriids of the Santacrucian (early Miocene, Flynn \& Swisher, 1995): Diadiaphorus majusculus Ameghino, 1887;
A
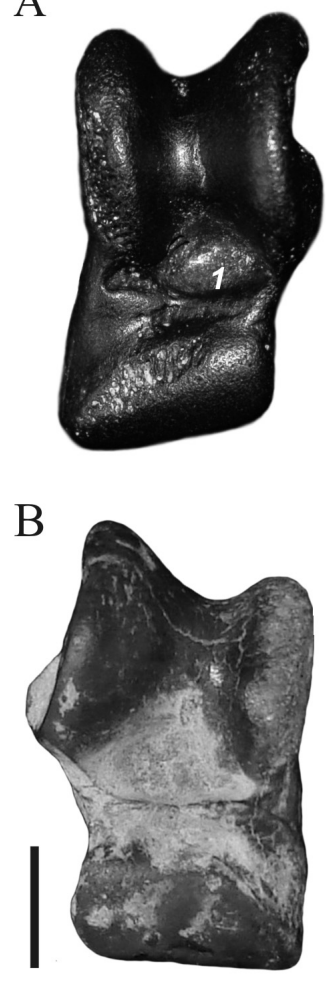

C

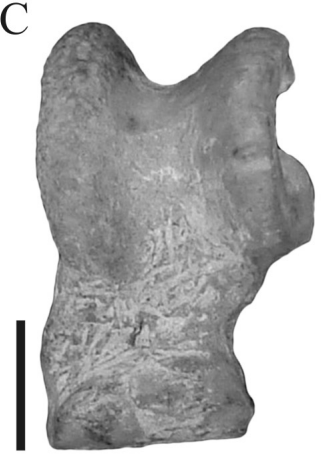

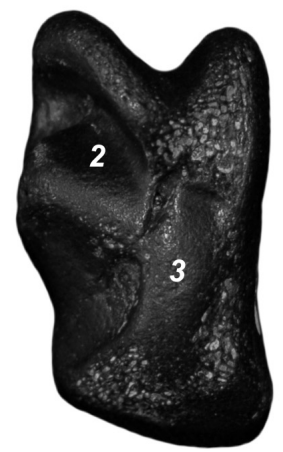
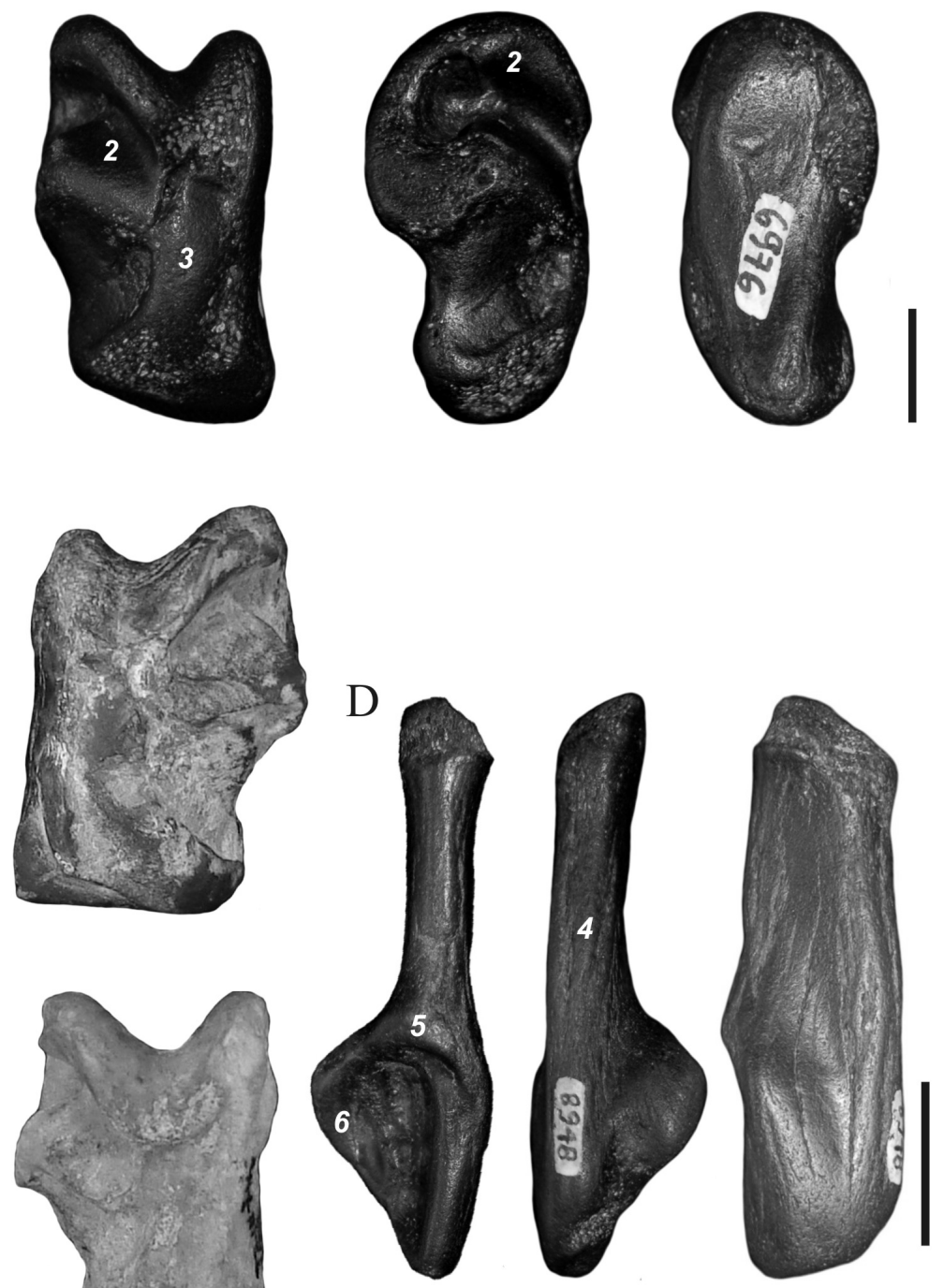

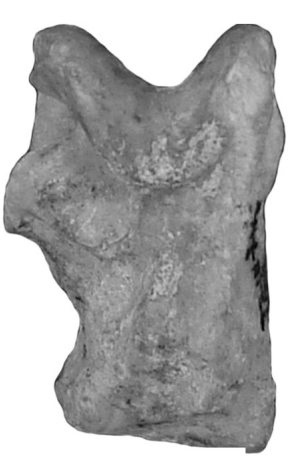

Figure 3. A, cf. Neolicaphrium recens, MCN-PV 6976, left astragalus in dorsal, plantar, lateral and medial views (left to right) (1. neck base fossa; 2. ectal facet; 3. sustentacular facet); B, Eoauchenia primitiva, MLP 12-2401, right astragalus, in dorsal (left) and plantar (right) views; C, Epecuenia thoatherioides, MLP 37-III-7-12, left astragalus, in dorsal (left) and plantar (right) views; D, cf. Neolicaphrium recens, MCN-PV 8948, left calcaneum in dorsal (left), plantar (center) and lateral (right) views (4. calcaneal body; 5 . ectal facet; 6 . sustentacular facet). Scale bars $=10 \mathrm{~mm}$. 
Thoatherium minusculum Ameghino, 1887; Anisolophus floweri (Ameghino, 1887); Tetramerorhinus mixtum (Ameghino, 1894); Tetramerorhinus cingulatum (Ameghino, 1891) (Scott, 1910; Soria, 2001); Huayquerian (late Miocene, Flynn \& Swisher, 1995): Epecuenia thoatherioides Cabrera, 1939; and Montehermosan (early Pliocene, Flynn \& Swisher, 1995): Eoauchenia primitiva Ameghino, 1888 (Cabrera, 1939; Soria, 2001) (Table 1 and 2, Figure 3). Unfortunately, there is no astragalus or calcaneum preserved for Neolicaphrium recens, the only species known for the Pleistocene.

The proterotherid astragali are very similar, but it is possible to observe that MCN-PV 6976 differs from $D$. majusculus and Tetramerorhinus mixtum in the absence of trochlea inclination, and from Eoauchenia primitiva and Epecuenia thoatherioides by the head projected distomedially.

A line graph was made (Figure 4A) comparing the available measurements of the species of the above mentioned Proterotheriidae. According to this graph and Table 1, it was observed that MCN-PV 6976 differs from A. floweri (AMNHN 9271, 15711), D. majusculus (AMNH 9196) and Eoauchenia primitiva (MLP 12-2401), by its small size, mainly in the mediolateral diameter and length, but shows a mediolateral diameter of the head similar to that of Epecuenia thoatherioides (MLP 37-III-7-12, 37-III-7-4) and Tetramerorhinus cingulatum (AMNH 15436) and Tetramerorhinus mixtum (AMNH 15107). The studied specimen differs from Thoatherium minusculum (AMNH 9167 and 15719) by the greater size in all compared measurements. Thus, MCN-PV 6976 is similar to Tetramerorhinus and Epecuenia thoatherioides in size, although this latter species has slightly greater mediolateral diameter and length, showing that these are smaller forms than in Anisolophus, Diadiaphorus and Eoauchenia.

The general aspect of the calcaneum is similar to that of other compared Proterotheriidae, differing from Thoatherium by the greater sustentacular facet, smaller concavity of cuboid facet and absence of fibular facet and third facet on the ectal protuberance referred to by Bergqvist et al. (1997). However, the absence of these last facets is not considered here as very relevant because they could disappear due to the abrasion process suffered during the reworking of the material. Relative to the size, the specimen MCN-PV 8948 is smaller than Diadiaphorus majusculus and Anisolophus floweri, with its measurements being closer to that of Tetramerorhinus cingulatum and Thoatherium minusculum (Table 2, Figure 4B).

Neolicaphrium recens is the only species recorded for the Pleistocene, in the Argentinean provinces of Córdoba (Pampean Formation, Ensenadan and Bonaerian), Corrientes (Yupoí Formation, ?Bonaerian) and Santa Fe (Tezanos Pinto Formation, Lujanian) (Alvarez, 1974; Tauber, 2000; Bond et al., 2001; Vezzosi et al., 2009), and in Uruguay in the Salto Departament (Sopas Formation, Lujanian) (Perea et al., 1998; Bond et al., 2001; Ubilla et al., 2007). At this moment, all the finds assigned to this species are skull, mandible, teeth and some carpal bones. Moreover, as there is no homologous material of tarsal bones of $N$. recens, it is impossible to safely attribute the specimens MCN-PV 6976 and 8948 to this species. Therefore, these material, like others known for Neolicaphrium, show small size (similar to forms of Thoatherium minusculum, Epecuenia thoatherioides and Tetramerorhinus mixtum) and because these finds have a pleistocenic age, we decided to assign them to cf. Neolicaphrium recens, confirming the presence of proterotherids in the Quaternary of the Rio Grande do Sul State, Brazil. This tentative attribution of the astragalus and the calcaneum to $N$. recens is also in accordance with the geographical distribution of the other finds of this taxon, in the same restricted latitudinal range in Argentina, Uruguay and now in southern Brazil.

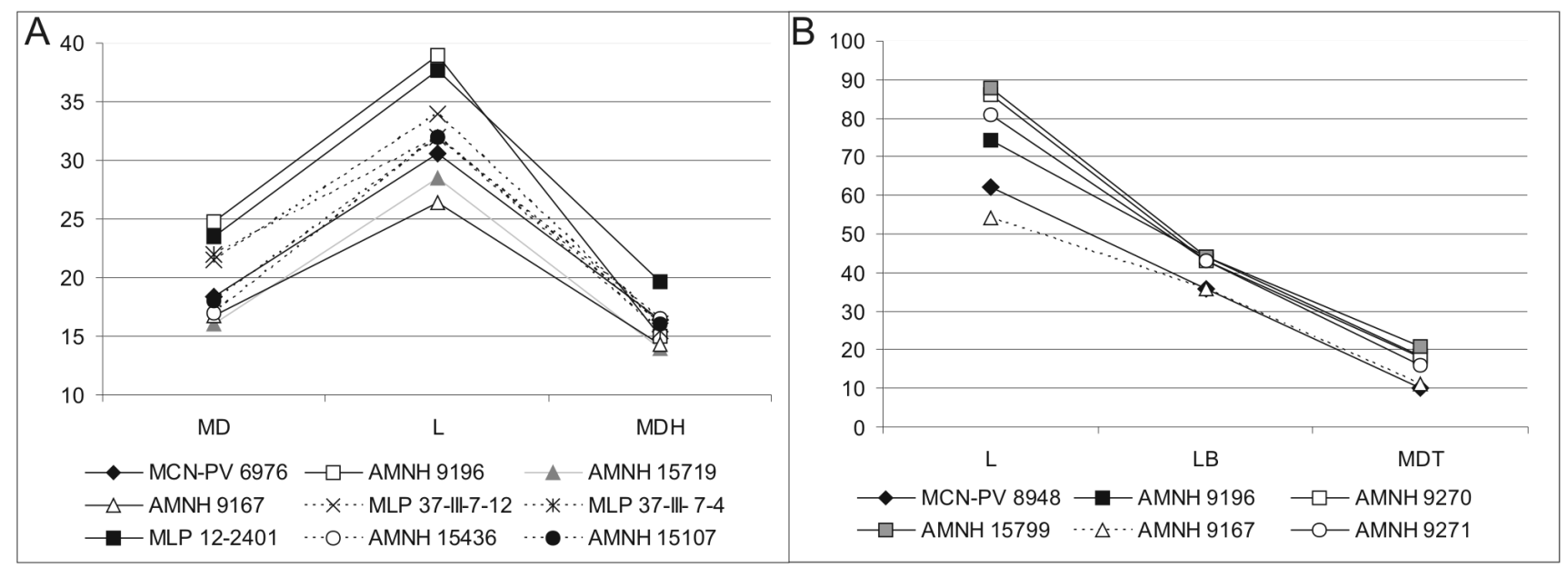

Figure 4. Line graphs. A, comparing the measurements of mediolateral diameter (MD), length (L) and mediolateral diameter of the head (MDH) of the astragali of cf. Neolicaphrium recens (MCN-PV 6976), Diadiaphorus majusculus (AMNH 9196), Thoatherium minusculum (AMNH 15719, 9167), Epecuenia thoatherioides (MLP 37-III-7-12, 37-III-7-4), Eoauchenia primitiva (MLP 12-2401), Tetramerorhinus cingulatum (AMNH 15436) and Tetramerorhinus mixtum (AMNH 15107); B, comparison of the measurements of length (L), length of the body (LB) and mediolateral diameter of tuberosity (MDT) of calcanea of cf. Neolicaphrium recens (MCN-PV 8948), Diadiaphorus majusculus (AMNH 9196, 9270, 15799), Thoatherium minusculum (AMNH 9167), and Anisolophus floweri (AMNH 9271). 
Table 1. Measurements of astragali of Proterotheriidae. Abbreviations: DC, distance between the two crests; DD, dorsoplantar diameter; DDH, dorsoplantar diameter of the head; L, length; LMd, length of the middle portion (between the two crests); MD, mediolateral diameter; MDH, mediolateral diameter of the head. 'from Scott (1910), "measurements taken from photographs.

\begin{tabular}{|c|c|c|c|c|c|c|c|c|}
\hline Taxon & Specimen Number & DC & DD & DDH & $\mathrm{L}$ & LMd & MD & $\mathrm{MDH}$ \\
\hline cf. Neolicaphrium recens & MCN-PV 6976 & 12.1 & 16.2 & 12.2 & 30.6 & 26.8 & 18.4 & 16.4 \\
\hline \multirow[t]{2}{*}{ Diadiaphorus majusculus } & AMNH 9196 & 19.0 & 26.0 & 11.7 & 39.0 & 32.8 & 24.8 & 15.0 \\
\hline & AMNH $15799^{1}$ & - & - & - & 44.0 & - & 26.0 & - \\
\hline \multirow[t]{2}{*}{ Thoatherium min us culum } & AMNH $15719^{1}$ & - & - & - & 28.5 & - & 16.0 & 14.0 \\
\hline & AMNH 9167 & 10.7 & 18.2 & 10.4 & 26.4 & 22.7 & 16.7 & 14.3 \\
\hline \multirow[t]{2}{*}{ Epecuenia thoatherioides } & MLP 37-III-7-12* & 13.5 & 21.5 & 11.3 & 34.0 & 29.0 & 21.5 & 16.0 \\
\hline & MLP $37-$ III- 7-4 & 12.5 & 20.0 & 10.5 & 32.0 & 27.5 & 22.0 & 15.5 \\
\hline Eoauchenia primitiva & MLP $12-2401^{*}$ & 14.0 & 22.0 & 16.0 & 37.7 & 31.0 & 23.5 & 19.7 \\
\hline \multirow[t]{2}{*}{ Anisolophus floweri } & $\mathrm{AMNH} 9271^{1}$ & - & - & - & 41.0 & - & 23.0 & - \\
\hline & AMNH $15711^{1}$ & - & - & - & 38.5 & - & 21.0 & - \\
\hline Tetramerorhinus cingulatum & AMNH $15436^{1}$ & - & - & - & 32.0 & - & 17.0 & 16.5 \\
\hline Tetra merorhinus mixtum & $\mathrm{AMNH} 15107^{1}$ & - & - & - & 32.0 & - & 18.0 & 16.0 \\
\hline
\end{tabular}

Table 2. Measurements of calcanea of Proterotheriidae. Abbreviations: DD, dorsoplantar diameter; L, length; LB, length of the body; MD, mediolateral diameter; MDT, mediolateral diameter of tuberosity. ${ }^{1}$ from Scott (1910), "approximate measurements.

\begin{tabular}{|c|c|c|c|c|c|c|}
\hline Taxon & Specimen Number & DD & $\mathrm{L}$ & LB & MD & MDT \\
\hline cf. Neolicaphrium recens & MCN-PV 8948 & 21.0 & $62.0^{*}$ & $35.8^{*}$ & 15.9 & $10.0^{*}$ \\
\hline \multirow[t]{3}{*}{ Diadiaphorus majusculus } & AMNH9196 & 30.0 & $74.3^{*}$ & 44.2 & 26.0 & 18.4 \\
\hline & AMNH $9270^{1}$ & - & 86.0 & 43.0 & - & 18.0 \\
\hline & AMNH $15799^{1}$ & - & 88.0 & 44.0 & - & 21.0 \\
\hline \multirow{2}{*}{ Thoatherium min us culum } & AMNH $15719^{1}$ & - & 56.0 & - & - & - \\
\hline & AMNH 9167 & 21.2 & 54.0 & 35.6 & 15.6 & 11.0 \\
\hline Anisolophus floweri & AMNH $9271^{1}$ & - & 81.0 & 43.0 & - & 16.0 \\
\hline \multirow[t]{2}{*}{ Tetra merorhinus cingulatum } & AMNH $15436^{1}$ & - & 64.5 & - & 24.0 & 16.0 \\
\hline & AMNH $15712^{1}$ & - & 69.0 & - & 23.0 & 15.0 \\
\hline
\end{tabular}

Superfamily MACRAUCHENIOIDEA Gervais, 1855

Family MACRAUCHENIIDAE Gervais, 1855

Subfamily MACRAUCHENIINAE Gervais, 1855

Macrauchenia Owen, 1838

Macrauchenia patachonica Owen, 1838

(Figures 5-6, Tables 3-6)

Material. MCN-PV 1487, incomplete right dentary with the symphyseal region; MCN-PV 2160 and 8842, incomplete thoracic vertebrae; MCN-PV 324 and 437, distal portions of left and right humeri, respectively; MCN-PV 3155, distal portion of right tibia and fibula; MCN-PV 7283 and 8083, left astragali; UFSM 11184, right astragalus; MCN-PV 1476, left metatarsal II.

Geographical provenance. MCN-PV 2160 from Touro Passo Creek (Uruguaiana); MCN-PV 1487, 1476 from Sanga da Cruz Creek (Alegrete); UFSM 11184 from Sanga Borba Creek (Pantano Grande); MCN-PV 8842, 324, 437, 7283, 8083 from Hermenegildo Beach (Santa Vitória do Palmar); MCN-PV 3155 from Chuí Creek (Santa Vitória do Palmar).

Description. The partial mandible (MCN-PV 1487, Figure 5) includes the symphyseal region, with the alveoli of right and left $\mathrm{I}_{1-3}$, right $\mathrm{C}$ and $\mathrm{P}_{1}$; the left $\mathrm{C}$ and the incomplete right dentary with $\mathrm{P}_{2}-\mathrm{M}_{3}$ are also preserved. The symphyseal region is strongly fused and laterally expanded. The dentary body is elongated, lower in the anterior portion becoming gradually higher until the posterior region. The ventral margin is rounded and slightly convex. The lateral surface is flat and slightly anteroposteriorly concave, with three foramina in the anterior portion. The first one, located at the $\mathrm{P}_{2}$ level, is greater and oval-shaped, the second one, at the $\mathrm{P}_{4}$ level, is similar to the first but smaller in size, and the third one, at the $\mathrm{M}_{1}$ level, is the smallest and rounded. The medial face is convex, mainly at the $\mathrm{M}_{3}$ level. The mandible ramus is thinner and expanded dorsally in the coronoid process about $25 \mathrm{~mm}$ from the $\mathrm{M}_{3}$. The coronoid process extends dorsally in an obtuse angle (more than $90^{\circ}$ ) in relation to the alveolar margin, with its anterior margin very straight. This process becomes very narrow in its dorsal portion, the dorsal portion being fractured. The mandibular notch is shallow and extends ventrally $15 \mathrm{~mm}$ from the dorsal margin of the mandibular condyle, where there is an increase in the lateromedial diameter of the ramus. The dorsal surface of the mandibular notch is continuous with the condylar articular facet, which is partially fractured, and the preserved portion is flat and posteriorly turned. The posterior margin of the ramus, which participates in the angular process, is thin and extends in an almost square angle in relation to the condyle. In spite of the posterior portion being fractured, it is possible to observe that the angular process passes posterior to the condyle level, as well as passing ventral to the dentary body. The mandibular foramen is oval and very deep, located about 30 $\mathrm{mm}$ below the alveolar margin, opening posteriorly in a wide elliptical fossa, whose dorsal margin is more evident than the ventral one.

In the specimen MCN-PV 1487, the $\mathrm{I}_{1-3}$ alveoli are triangular, while the $\mathrm{C}$ alveolus is rounded and that of $\mathrm{P}_{1}$ is elliptical, with a larger mesiodistal diameter. The left canine is spatulate and has two shallow grooves separated by a longitudinal crest on the lingual face. The premolars and molars show a rectangular general pattern elongated in the mesiodistal direction and implanted parallel to the dentary. The $\mathrm{P}_{2-3}$ are 
buccolingually narrower than the other teeth and have few marked ectoflexids. In the premolars, the metaconid is well developed and represents the highest portion of the tooth, and the lingual basal cingulum borders the two grooves on both sides of the metaconid. The $\mathrm{P}_{4}$ is molariform with the hypoconid and the paraconid well developed, ectoflexids more marked and metaconid more robust than in $\mathrm{P}_{2-3}$, and ento- and metaflexids very deep. The molars do not show an entolophid, the metaconid is very wide and para- and entoconids are less developed, although they are fractured in $\mathrm{M}_{2-3}$. The $\mathrm{M}_{1}$ shows narrower and flatter ectoflexids than in $\mathrm{M}_{2-3}$, which are broad and deep. In the molars and in the $\mathrm{P}_{4}$, the talonids and trigonids are buccally rounded, except the $\mathrm{M}_{3}$ talonid which is $\mathrm{V}$-shaped.

The thoracic vertebra (MCN-PV 2160, Figure 6A) is almost complete, lacking just the most dorsal portion of the neural spine. The neural canal is triangular, and the centrum is rounded in cross-section and slightly convex on the cranial face and oval section, and flattened on the caudal face. On both faces, the centrum is bordered laterally by the facets for the rib capitulum. These facets are ventrally turned, with elliptical outline and very concave on the cranial face, while the facets of the caudal face are caudally turned, subcircularshaped and less concave than that previously cited. The transverse process is short and robust, and shows the facet for the tubercle rib, which is not clear due to preservation. The postzygapophyses have a rounded outline and the prezygapophyses are obliterated by concretion (due fragility, the specimen was not prepared). Because this vertebra is isolated, it is not possible to recognize its position in the vertebral sequence. The other thoracic vertebra (MCN-PV 8842) is incomplete, lacking the neural spine, part of the neural arch, the cranial and caudal faces of the vertebral body and part of the transverse processes. However, it is possible to recognize the wide capitulum's facets, which shows a morphologic pattern similar to that of specimen MCN-PV 2160.

The incomplete humeri (MCN-PV 324 and 437) (Figures $6 \mathrm{~B}, \mathrm{C})$ show just the distal portions and a small part of the body; both specimens show signs of reworking. The humerus is relatively robust with the distal portion widened gradually relative to the body, and the most distal mediolateral diameter is at the epicondylar level. The medial and lateral faces of the distal portion are flattened. The condyles are wide and similar to each other in morphology and size, the lateral one being slightly more expanded distally while the medial one anteroposteriorly thicker. In anterior view, the trochlea is bordered by the shallow and subcircular coronoid fossa and, posteriorly, by the deep and elliptical olecranon fossa. The ectepicondyle is more developed than the entepicondyle.

The specimen MCN-PV 3155 (Figure 6D) corresponds to a distal fragment of tibia and fibula partially fused, lacking the anterior portion of the tibia. Because of the fragmentation of this material, it was impossible to take its measurements. The medial and posterior faces of tibia are smooth and flat, becoming slightly rugose near the articular distal portion. The distal articular facet of the tibia is characterized by two concavities with rounded outline separated by a thick rounded and broad crest, which articulates with the astragalar

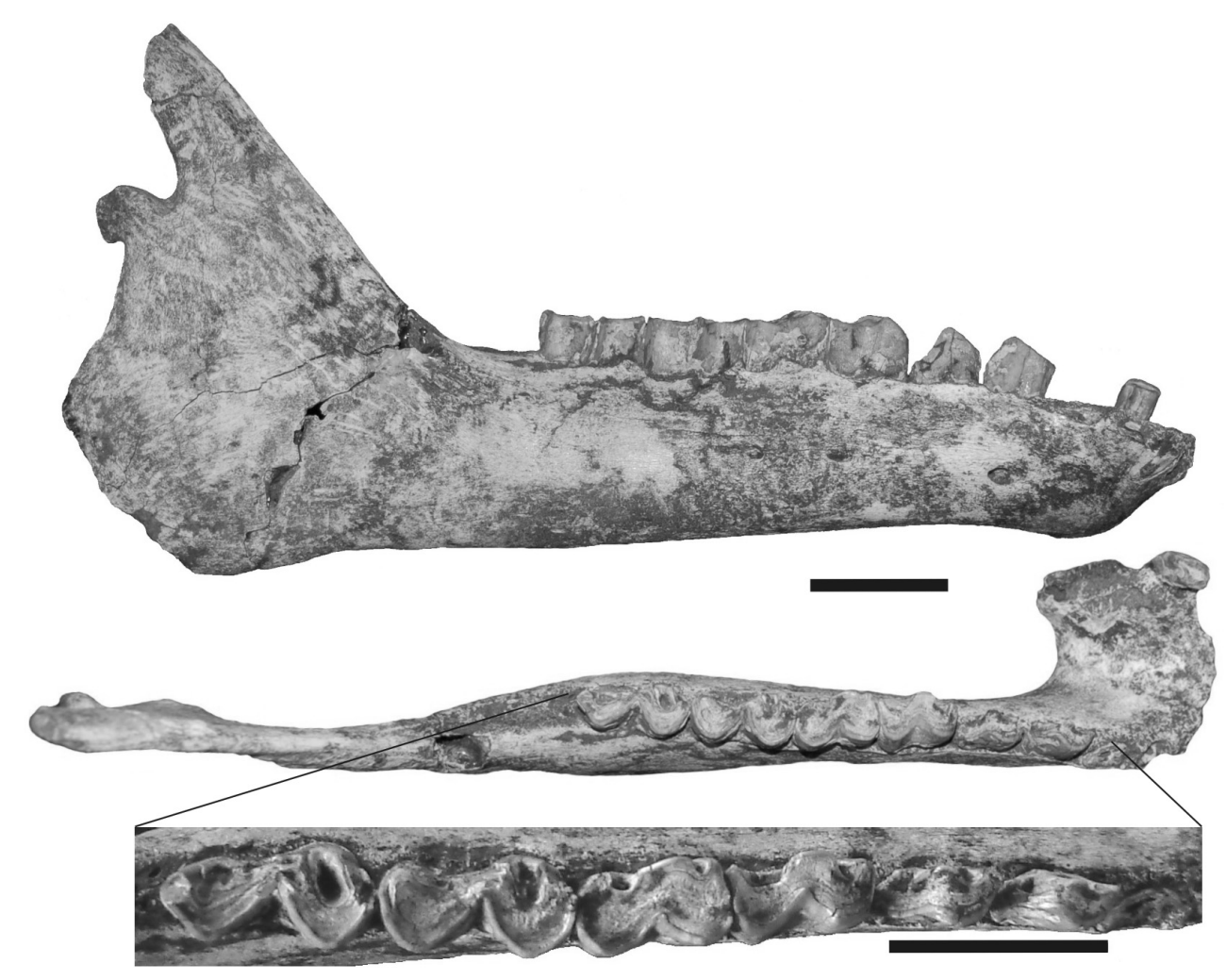

Figure 5. Macrauchenia patachonica, MCN-PV 1487, mandible fragment in lateral (top) and occlusal (middle and bottom) views. Scale bars $=50 \mathrm{~mm}$. 
trochlea. The fibula has two articular facets; the first one is medially turned, narrow, and slightly concave and articulates with the fibular facet of the astragalus. The other facet is distally turned, similar to the first one but more concave anteriorly and articulates with the calcaneum.
The astragali MCN-PV 7283, 8083 and UFSM 11184 (Figures $6 \mathrm{E}-\mathrm{G})$ are relatively well preserved; the first two show the major part of the plantar portion eroded, with just the ectal facet remaining. The third astragalus has the lateral crest fractured, but the ectal and sustentacular facets are intact.
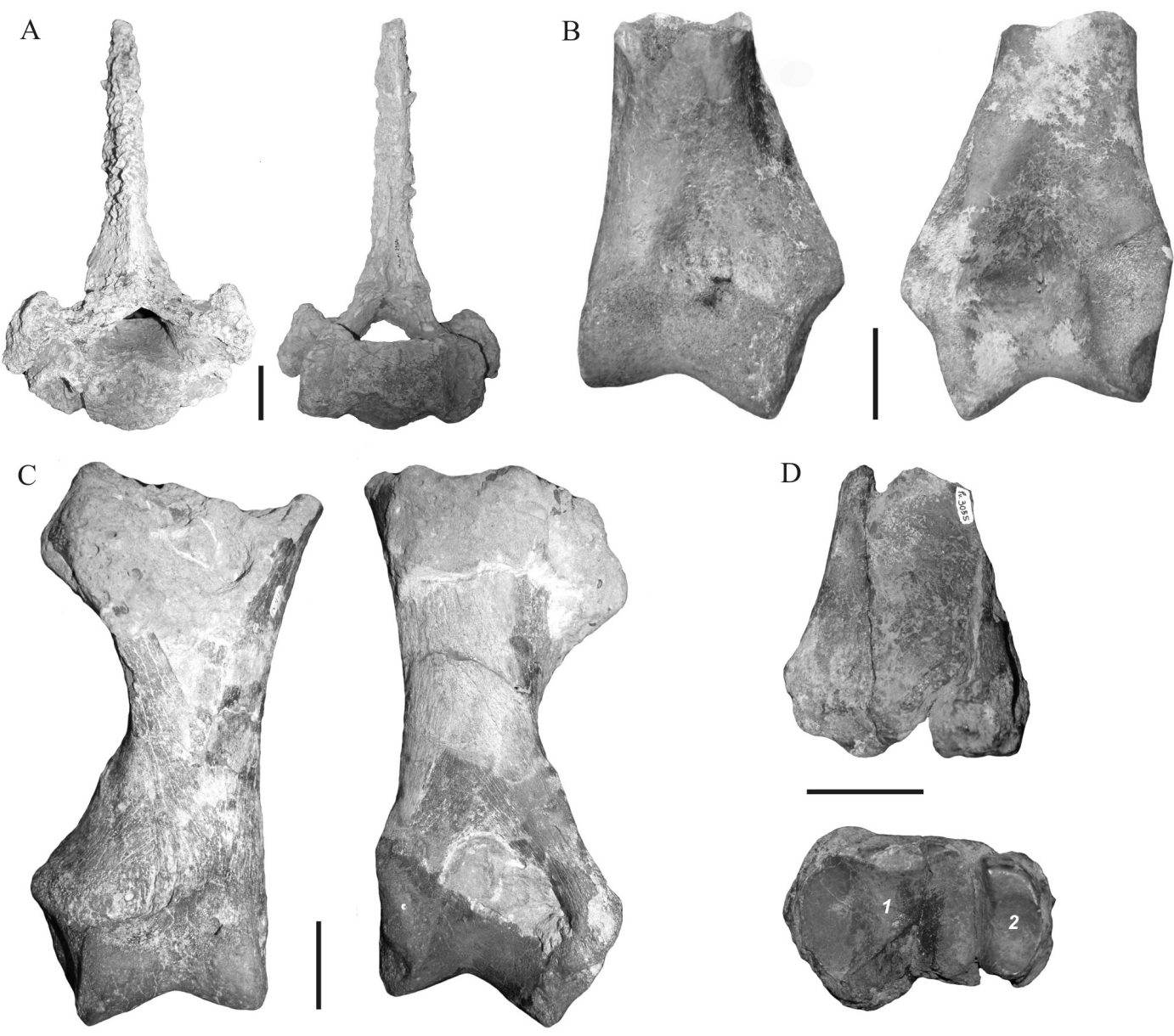
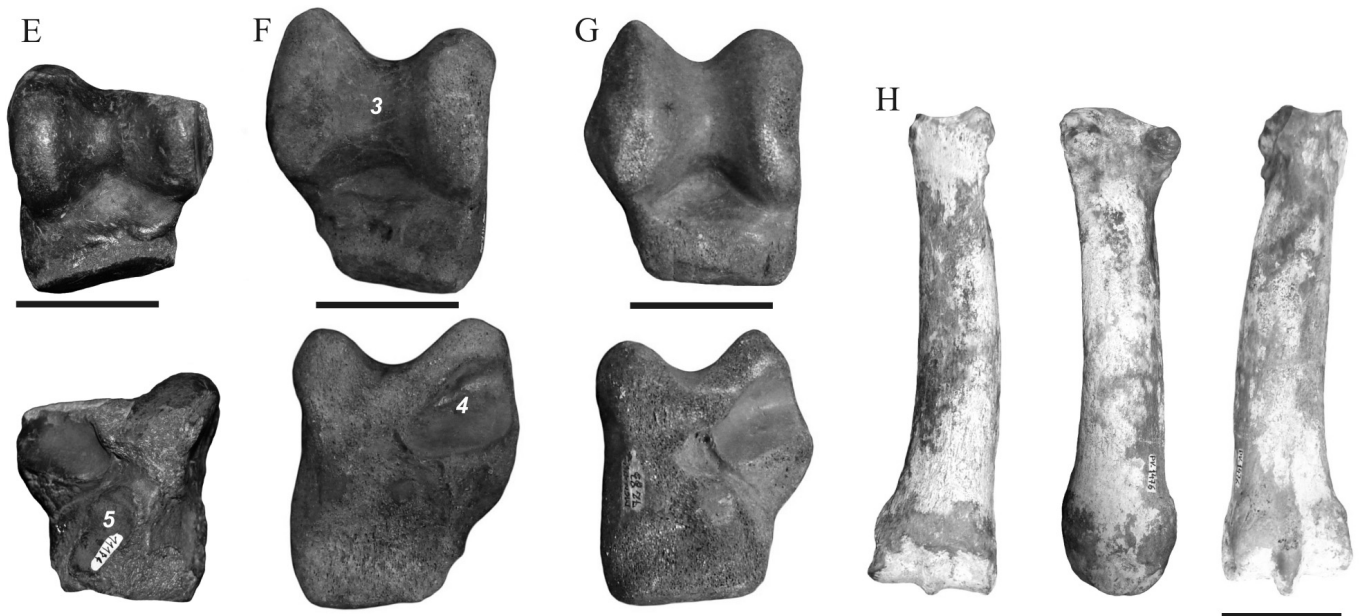

Figure 6. Macrauchenia patachonica. A, MCN-PV 2160, complete thoracic vertebra in cranial (left) and caudal (right) views; B, MCN-PV 324, distal portion of left humerus; C, MCN-PV 437, distal portion of right humerus, both in anterior (left) and posterior (right) views; D, MCN-PV 3155 distal portion of right tibia and fibula in anterior (top) and distal (bottom) views (1. astragalar facet of tibia; 2 . calcaneal facet of fibula); E, UFSM 11184, right astragalus; F, MCN-PV 8083, left astragalus. G, MCN-PV 7283, left astragalus, all in dorsal (top) and plantar (bottom) views (3. astragalar trochlea, 4. ectal facet, 5. sustentacular facet); H, MCN-PV 1476, left metatarsal II in dorsal (left), medial (center) and plantar (right) views. 
The astragali are quadrangular-shaped; the medial and distal portions of the lateral surface are rugose and flat, while the proximal portion of the lateral surface shows a wide fibular facet, which is eroded in MCN-PV 7283 and 8083 and incomplete in UFSM 11184. The proximal portion of the astragalus, the trochlea, is wider than the distal portion, the astragalar head. The trochlea is pulley-shaped, large with rounded crests separated by a wide and shallow groove, and covers about two-thirds of the dorsal surface, reaching just a small portion of the plantar surface. The lateral crest is more proximally extended than the medial one. The neck is short and bears the neck base fossa, which is wide and very concave. The neck is not clearly differentiated from the astragalar head, having just a small lateral constriction, best observed in UFSM 11184. The head is characterized by a convexity at the border with the neck, becoming flat in the articular facet for the navicular. The ectal facet is lateromedially elongated, and the sustentacular one is flat and elongated proximodistally and narrow lateromedially. These two facets are separated by a narrow and deep groove.

The specimen MCN-PV 1476 (Figure 6H) is a left metatarsal II, which is elongated with a total length of about $195 \mathrm{~mm}$. Its medial face is slightly convex and the lateral one shows a curvature more evident near the distal portion. The medial and dorsal faces are flat and smooth, and a short and low crest arises near the proximal articular facet and extends distally. The distal portion is wide relative to the proximal one, the mediolateral diameters being $50.1 \mathrm{~mm}$ and $32.3 \mathrm{~mm}$, respectively. On the other hand, the proximal portion is thicker than the distal one, being about $49.1 \mathrm{~mm}$ and $43.3 \mathrm{~mm}$, respectively. The semilunar proximal articular portion is narrow lateromedially and elongated in the dorsoplantar direction. The proximal lateral articulation has two facets separated by a distance of $20 \mathrm{~mm}$. The dorsal facet of lateral face is concave and lies $10 \mathrm{~mm}$ below the margin of the proximal articular facet. The plantar facet of lateral face is flat and rounded, and continues with the proximal facet. The distal articular facet is rounded, extending on the dorsal and plantar faces, being divided in two parts by a central crest, which is more prominent on the plantar face.

Discussion. The material of the Macraucheniidae from Rio Grande do Sul State was compared, with specimens from Argentina attributed to Macraucheniopsis ensenadensis by Paula-Couto (1945); Macrauchenia patachonica, from Argentina described by Owen (1838), Pascual et al. (1966) and Ferrero (2009), and material from Bolivia and northeastern of Brazil attributed to this species by Guérin \& Faure (2004); and with Xenorhinotherium bahiense, from northeastern and southeastern Brazil described by Cartelle \& Lessa (1988), as well as with that described by Vidal (1955) attributed to Macrauchenia patachonica. The postcranial elements could not be compared with $M$. ensenadensis because there are not homologous elements referable to this species; and the postcranial material associated with the type of $X$. bahiense is still under study (G. Lessa, personal communication).

The specimen MCN-PV 1487 previously studied by Oliveira (1992) and Lessa \& Oliveira (1996), was revaluated on the basis of other characters, material as well compared to new specimens of $X$. bahiense and Macrauchenia patachonica described posteriorly. This specimen was compared with the Macraucheniidae forms described for the South American Pleistocene: Macraucheniopsis ensenadensis, from the Ensenadan of the Pampean region of Argentina (Paula-Couto, 1945); Xenorhinotherium bahiense, from the late Pleistocene of northeastern Brazil (Cartelle \& Lessa, 1988, and the material described by Vidal, 1955 as Macrauchenia patachonica); Macrauchenia patachonica, from the Lujanian of Pampean region of Argentina (Vidal, 1955; Pascual et al., 1966) and the material from northeastern Brazil and Bolivia studied by Guérin \& Faure (2004) (Tables 3-4). The specimen MCN-PV 1487 differs from Macraucheniopsis ensenadensis and X. bahiense by the wider symphyseal region and anterior border laterally expanded, $\mathrm{P}_{4}$ and $\mathrm{M}_{1}$ with similar mesiodistal length, shorter molars and canines, and premolars implanted parallel to dentary, characters present in Macrauchenia patachonica. The dentary MCN-PV 1487, as in Macrauchenia patachonica, differs from Macraucheniopsis ensenadensis by the anteroposteriorly compressed and lateromedially enlarged condyle, smaller teeth (Table 4) and low dentary (Table 3) (Paula-Couto, 1945), where the last character is also observed in X. bahiense. Relative to dentition, MCN-PV 1487 differs from $X$. bahiense by the absence of an entolophid in the $\mathrm{P}_{4}$ and $\mathrm{M}_{1-2}$, by the rounded shape of talonids and trigonids and shallow ectoflexids of these teeth; these characters are similar to those of Macrauchenia patachonica and Macraucheniopsis ensenadensis (Cartelle \& Lessa, 1988). Comparing the studied material with that referred to by Guérin $\&$ Faure (2004), it was observed that the Rio Grande do Sul specimen is smaller than that from São Raimundo Nonato, Piauí State (FUMDHAM s/n ${ }^{\circ}$ ) and that of Tarija (TAR 816), in all measurements of the teeth. These specimens also differ from MCN-PV 1487 by a $\mathrm{P}_{4}$ longer than the $\mathrm{M}_{1}$, like in Macraucheniopsis ensenadensis and $X$. bahiense. However, this character, often used to distinguish these taxa (Macrauchenia patachonica with $\mathrm{P}_{4}$ and $\mathrm{M}_{1}$ with similar length, and $X$. bahiense and Macraucheniopsis ensenadensis with the $\mathrm{P}_{4}$ longer) (Cartelle \& Lessa, 1988) can be variable, because there are specimens of Macrauchenia patachonica (MACN Pv 2, from Argentina) with $\mathrm{P}_{4}$ longer than $\mathrm{M}_{1}$, as well others attributed to X. bahiense by Cartelle \& Lessa (1988), with these two teeth being similar in length (MNRJ 01-V, from Pernambuco) or even $\mathrm{M}_{1}$ being longer than the $\mathrm{P}_{4}$ (DGM 151-M, from Bahia). Relative to tooth size, it was observed that MCN-PV 1487 is similar to Macrauchenia patachonica (Table 4). In the graph comparing the length measurements of the teeth $\left(\mathrm{P}_{4}\right.$ and $\left.\mathrm{M}_{1-3}\right)$ of Pleistocene Macraucheniidae (Figure 7A), it is evident that the $P_{4}$ length is the most representative measurement to differentiate Macrauchenia patachonica from X. bahiense and Macraucheniopsis ensenadensis, while in the $M_{1}$ and $M_{2}$ length there is a specimen attributed to Macraucheniopsis cf. M. ensenadensis by Cartelle \& Lessa (1988) (MACN Pv 11450, from Argentina) showing similarity to Macrauchenia patachonica. On the other hand, the $\mathrm{M}_{3}$ 
length is not a representative measurement in the size distinction between these species, because there is a specimen of Macrauchenia patachonica where tooth size is within the variation of Macraucheniopsis ensenadensis and $X$. bahiense, and a specimen of $X$. bahiense among the Macrauchenia patachonica with regard to tooth size. Besides this, a specimen of Macraucheniopsis ensenadensis has a
$M_{3}$ length much greater than the others of the analyzed material. Also, a graph was made comparing the length of $\mathrm{P}_{3}$ to $\mathrm{M}_{2}$ measurements, to include a greater number of comparable specimens, mainly those from São Raimundo Nonato and Tarija. In the graph (Figure 7B), it was possible to observe that the length of $\mathrm{P}_{3}$ and $\mathrm{P}_{4}$ are the most representative measurements to distinguish Macrauchenia patachonica

Table 3. Measurements of dentaries of Macraucheniidae. Abbreviations: $\mathbf{D M}_{1}$, depth of dentary at the $\mathbf{M}_{1}$ level; $\mathbf{D M} \mathbf{M}_{3}$, depth of dentary at the $\mathrm{M}_{3}$ level; $\mathbf{L D}$, length of dentary from the posterior condylar limit until the anterior symphyseal edge; $\mathbf{M D M}_{1}$, mediolateral diameter of dentary at the $\mathrm{M}_{1}$ level; $\mathbf{M D M}_{3}$, mediolateral diameter of dentary at the $\mathrm{M}_{3}$ level. ' from Paula-Couto (1945), ${ }^{2}$ Paula-Couto (1947), ${ }^{3} \mathrm{Vidal}$ (1955), ${ }^{4}$ Ferrero (2009).

\begin{tabular}{|c|c|c|c|c|c|c|}
\hline Taxon & Specimen Number & $\mathrm{DM}_{1}$ & $\mathrm{DM}_{3}$ & LD & $\mathrm{MDM}_{1}$ & $\mathrm{MDM}_{3}$ \\
\hline \multirow[t]{5}{*}{ Macrau chenia patachonica } & MCN-PV 1487 & 60.9 & 69.5 & 417.3 & 27.9 & 32.9 \\
\hline & MLP $1424^{1.2}$ & 54.0 & - & 455.0 & 29.0 & - \\
\hline & MLP $2465^{1.2}$ & 61.0 & - & 426.0 & 28.6 & - \\
\hline & MACN $2^{1.2 .3}$ & 63.0 & 71.4 & 438.0 & 29.0 & - \\
\hline & MGGC $s / n^{04}$ & 49.0 & 64.5 & - & - & - \\
\hline \multirow[t]{2}{*}{ Macrau cheniopsis ensenadensis } & MLP $1456^{1}$ & 70.0 & - & - & - & - \\
\hline & MLP $1426^{1}$ & 66.0 & - & 485.0 & - & - \\
\hline \multirow[t]{2}{*}{ Xenorhinotherium bahiense } & DGM 151-M ${ }^{2}$ & 57.2 & 74.0 & - & 29.0 & 38.0 \\
\hline & MNRJ 01- $\mathrm{V}^{3}$ & 47.0 & - & - & 29.0 & - \\
\hline
\end{tabular}

Table 4. Measurements of teeth of Macraucheniidae. Abbreviations: $P_{2} L, P_{2}$ length; $P_{2} W, P_{2}$ width; $P_{3} L, P_{3}$ length; $P_{3} W, P_{3}$ width; $P_{4} L, P_{4}$ length; $P_{4} W, P_{4}$ width; $M_{1} L, M_{1}$ length; $M_{1} W, M_{1}$ width; $M_{2} L, M_{2}$ length; $M_{2} W, M_{2}$ width; $M_{3} L, M_{3}$ length; $M_{3} W, M_{3}$ width. ${ }^{1}$ from $P$ aula-Couto (1945), ${ }^{2}$ Vidal (1955), ${ }^{4}$ Cartelle \& Lessa (1988), ${ }^{4}$ Paula-Couto (1947), ${ }^{5}$ Guérin \& Faure (2004), ${ }^{6}$ Ferrero (2009). "approximate measurements, " mean.

\begin{tabular}{|c|c|c|c|c|c|c|c|c|c|c|c|c|c|}
\hline Taxon & $\begin{array}{l}\text { Specimen } \\
\text { Number }\end{array}$ & $\mathrm{P}_{2} \mathrm{~L}$ & $\mathrm{P}_{2} \mathrm{~W}$ & $\mathrm{P}_{3} \mathrm{~L}$ & $\mathrm{P}_{3} \mathrm{~W}$ & $\mathrm{P}_{4} \mathrm{~L}$ & $\mathrm{P}_{4} \mathrm{~W}$ & $\mathrm{M}_{1} \mathrm{~L}$ & $\mathrm{M}_{1} \mathrm{~W}$ & $\mathrm{M}_{2} \mathrm{~L}$ & $\mathrm{M}_{2} \mathrm{~W}$ & $\mathrm{M}_{3} \mathrm{~L}$ & $\mathrm{M}_{3} \mathrm{~W}$ \\
\hline \multirow{7}{*}{$\begin{array}{l}\text { Macrauchenia } \\
\text { patachonica }\end{array}$} & MCN-PV 1487 & 24.3 & 10.8 & 24.3 & 12.3 & 30.0 & 15.8 & 29.7 & 18.2 & 37.2 & 18.8 & 40.1 & 18.5 \\
\hline & MLP $1424^{1}$ & 22.1 & 12.0 & - & - & 29.0 & 14.0 & 29.0 & 15.0 & 38.0 & 17.2 & 41.5 & 18.0 \\
\hline & MLP $2465^{1}$ & 22.5 & 12.5 & 25.2 & 14.2 & 31.3 & 15.7 & 32.0 & 19.8 & 37.2 & 20.3 & 43.0 & 22.6 \\
\hline & MACN $2^{2}$ & - & - & - & - & 29.8 & 15.7 & 27.4 & 20.3 & 36.5 & 20.0 & 38.8 & 18.5 \\
\hline & MGGC s $/ n^{\circ 6}$ & 229 & 8.5 & 26.4 & 12.0 & 32.4 & 17.7 & 29.8 & 21.2 & 39.3 & 21.9 & 45.9 & 21.6 \\
\hline & TAR $816^{\circ}$ & - & - & 38.5 & 16.0 & 43.0 & 20.0 & 39.0 & 21.5 & 48.5 & 22.5 & 49.0 & - \\
\hline & $\begin{array}{l}\text { FUMDHAM } \\
\mathrm{s} / \mathrm{n}^{05^{* *}}\end{array}$ & 26.8 & 13.8 & 30.3 & 14.2 & 38.0 & 17.0 & 36.6 & 19.5 & 43.3 & 19.5 & - & - \\
\hline \multirow{3}{*}{$\begin{array}{l}\text { Macrau cheniopsis } \\
\text { ensenadensis }\end{array}$} & MLP $1426^{1}$ & 29.0 & 14.2 & 30.5 & 14.0 & $37.0^{*}$ & $17.0^{*}$ & 35.0 & 19.7 & 47.5 & 19.2 & 47.0 & 18.0 \\
\hline & MLP $1456^{1}$ & 320 & 14.9 & 34.8 & 16.3 & 40.0 & 18.5 & 36.0 & 22.0 & 48.8 & 23.5 & 56.0 & 19.2 \\
\hline & MACN $11450^{3}$ & 28.0 & 13.3 & 30.0 & 14.0 & 36.5 & 15.6 & 33.0 & 19.4 & 41.0 & 19.0 & 45.4 & 17.8 \\
\hline \multirow{4}{*}{$\begin{array}{l}\text { Xenorhinotherium } \\
\text { bahiense }\end{array}$} & DGM $151-M^{4}$ & - & - & - & - & 32.4 & 14.9 & $38.8^{*}$ & 18.3 & - & - & 47.0 & 21.4 \\
\hline & MNRJ 01-V² & - & - & - & - & 36.0 & 17.0 & 36.0 & 18.0 & 40.0 & 18.0 & - & - \\
\hline & MCL $2644 / 02^{3}$ & 27.6 & 14.3 & 30.0 & 15.0 & 37.7 & 18.0 & 36.0 & 19.0 & 43.0 & 20.3 & 43.0 & 20.0 \\
\hline & MCL $3577^{3}$ & 30.5 & 13.5 & 33.0 & 13.0 & 37.6 & 17.0 & 36.0 & 18.0 & 46.0 & 18.0 & 46.0 & 17.4 \\
\hline
\end{tabular}
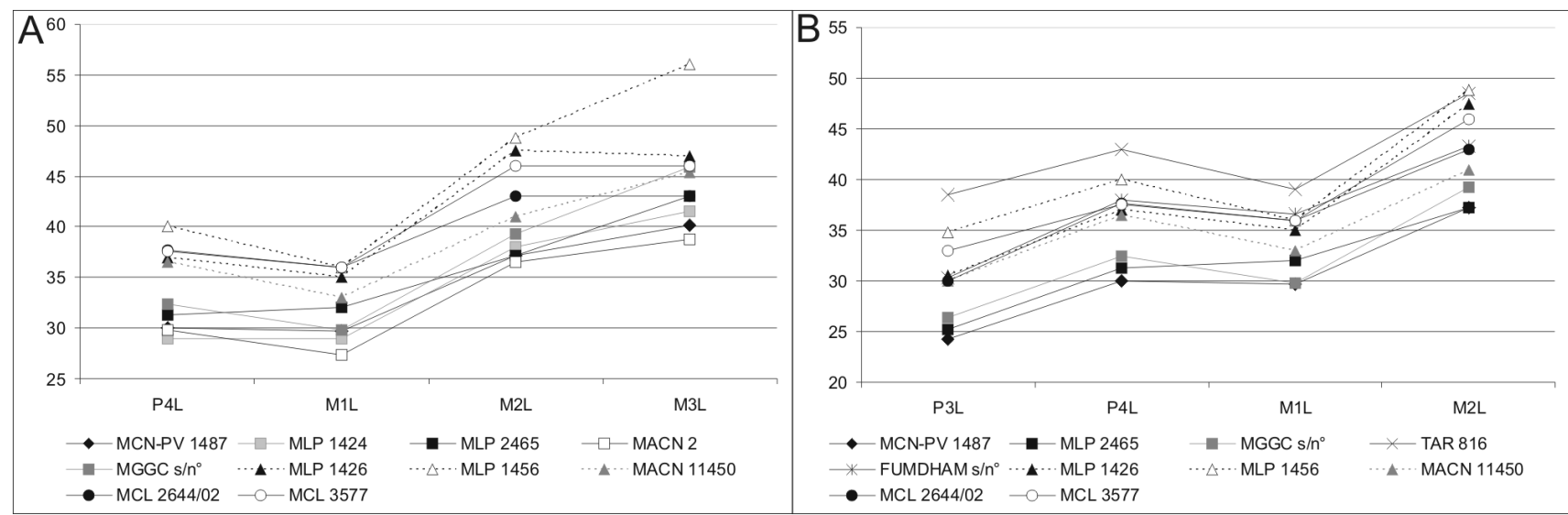

Figure 7. Line graphs. A, Comparison of the measurements of $P_{4}, M_{1-3}$ length ( $L$ ) of Macrauchenia patachonica (MCN-PV 1487, MLP 1424, 2465, MACN Pv 2, MGGC s/nº); Macraucheniopsis ensenadensis (MLP 1426, 1456, MACN Pv 11450) and Xenorhinotherium bahiense (MCL 2644/02 (holotype), 3577); B, Comparison of the measurements of $\mathrm{P}_{3-4}, \mathrm{M}_{1-2}$ length (L) of Macrauchenia patachonica (MCN-PV 1487, MLP 2465, MGGC s/nº, TAR 816, FUMDAHM s/n $\mathrm{n}^{\circ}$ ); Macraucheniopsis ensenadensis (MLP 1426, 1456, MACN Pv 11450) and Xenorhinotherium bahiense (MCL 2644/02, 3577). 
and the other species, confirming what was observed in the aforementioned graph (Figure 7A). Although the length of $M_{1}$ and, mainly $M_{2}$, did not permit the differentiation of the Macraucheniidae species, as observed in the aforementioned graph, the specimen MACN Pv 11450 (referred to Macraucheniopsis cf. M. ensenadensis) showed a measurement of $\mathrm{M}_{1-2}$ length very similar to that of Macrauchenia patachonica. On the other hand, it is possible to see that the specimens referred to by Guérin \& Faure (2004) as Macrauchenia patachonica (TAR 816 and FUMDHAM $\mathrm{s} / \mathrm{n}^{\circ}$ ) show values of measurements of the teeth within the variation of Macraucheniopsis ensenadensis and $X$. bahiense. In this way the specimen MCN-PV 1487 is attributed to Macrauchenia patachonica, on the basis of its similarity to the Argentinean specimens, than to X. bahiense or to Macraucheniopsis ensenadensis. We did not follow Guérin \& Faure (2004) proposition because they interpreted erroneously some dental and cranial features diagnostic of $X$. bahiense, in order to consider this species as synonym of Macrauchenia patachonica, for instance that in X. bahiense the entolophid occurs only in the $\mathrm{P}_{4}$, but not in $\mathrm{M}_{1-2}$. It is important a complete revision of the material studied by Guérin \& Faure (2004).

The thoracic vertebra (MCN-PV 2160) was previously reported by Scherer et al. (2006) and is here better described and discussed. The thoracic vertebrae (MCN-PV 2160, 8842) were assigned to Macrauchenia patachonica because its morphology and size compares well with that figured by Burmeister (1864). Moreover, the studied specimens show a greater size than MNRJ 211-V, from Pernambuco, which was referred to by Vidal $(1946,1955)$ as a lumbar vertebra, but analyzing this specimen we conclude that it is an incomplete thoracic vertebra that can be assigned to $X$. bahiense according to the proposal of Cartelle \& Lessa (1988). This is in according to Lessa \& Cartelle (1995), who considered that the vertebrae of Macrauchenia patachonica are greater than ones of $X$. bahiense.

Relative to the humeri, reported also by Scherer et al. (2006), here it were taken several measurements of the distal portion of specimens MCN-PV 324 and 437 (Table 5), which are smaller than the Argentinean material referred to by Burmeister (1864), Alvarez (1943) and Sefve (1925), and relative to the morphology, are very similar to that figured and described by these authors. The studied material is also smaller than the humerus from São Raimundo Nonato and that from Argentina (mediolateral diameter of $140.5 \mathrm{~mm}$ and anteroposterior diameter of $98.5 \mathrm{~mm}$ ) referred to by Guérin \& Faure (2004). On the other hand, when compared to the complete humerus from Pernambuco, described by Vidal (1955) (MNRJ 180-V), the specimens from Rio Grande do Sul are more robust, mainly MCN-PV 437. Vidal (1955) also presented measurements of the Macrauchenia patachonica humerus from the Pampean region of Argentina, where the distal mediolateral diameter is greater and the distal articular mediolateral diameter smaller than the material from Rio Grande do Sul. Thus, based on the humerus, it is not possible to differentiate the species of the Macraucheniidae from northeastern Brazil and those from the Pampean region, as already referred to by Cartelle \& Lessa (1988).

Because the tibia and fibula (MCN-PV 3155) are incomplete, it was impossible to obtain exact measurements; thus, its identification as Macrauchenia patachonica was based on comparative analysis with the illustration of the material referred to by Owen (1838). In spite the specimen is incomplete; it shows some features described by Owen (1838), like the tendinous groove in the lateral face of the fibula.

The astragali (UFSM 11184, MCN-PV 7283 and 8083, reported by Scherer et al. (2003, 2006)) do not show morphologic differences relative to that described and figured by Owen (1838). On the other hand, they differ from the specimen FUMDHAM 48901 (from Piauí State, figures 4 B, C of Guérin \& Faure (2004)), which has a plantar expansion of the trochlea, and an astragalar head with a lateral expansion, characters not observed in the MCN-PV 7283, 8083 and UFSM 11184. The last feature was observed also in the specimen MNRJ 09-V figured by Vidal (1955) as Macrauchenia patachonica, and considered as X. bahiense by Cartelle \& Lessa (1988). Relative to the size, (Table 6, Figure 8), MCNPV 7283 and 8083 have measurements within the variation observed for Macrauchenia patachonica from Argentina. These specimens from Rio Grande do Sul are larger in almost all measurements in comparison to the finds from São Raimundo Nonato, Piauí State (Toca da Barra do Antonião and Lagoa de São Vitor) (FUMDHAM 1648, 7955, 48901) studied by Guérin \& Faure (2004). However, the anteroposterior diameter of the astragalar head of specimens MCN-PV 7283 and 8083 had much smaller values than all compared specimens, which can be due to the erosion of this face on this material. The specimen UFSM 11184 is smaller than most of the astragali analyzed, being more similar in size with the material from Piauí. The material of $X$. bahiense from Pernambuco (MNRJ 09-V), referred to by Cartelle \& Lessa

Table 5. Measurements of humeri of Macraucheniidae. Abbreviations: ADD, anteroposterior diameter of distal portion; HOF, height of the olecranon fossa; MDD, mediolateral diameter of distal portion; MDDA, mediolateral diameter of distal articular surface; MDOF, mediolateral diameter of the olecranon fossa. ${ }^{1}$ from Vidal (1955), ${ }^{2}$ Guérin \& Faure (2004), ${ }^{3}$ Alvarez (1943).

\begin{tabular}{|c|c|c|c|c|c|c|}
\hline Taxon & Specimen Number & ADD & $\mathrm{HOF}$ & MDD & MDDA & MDOF \\
\hline \multirow[t]{6}{*}{ Macrau chenia patachonica } & MCN-PV 324 & 82.6 & 42.3 & 127.7 & 93.9 & 54.5 \\
\hline & MCN-PV 437 & 78.6 & - & 131.7 & 94.8 & 61.7 \\
\hline & MACN $9676^{3}$ & - & 41.4 & 144.0 & 83.0 & 58.0 \\
\hline & MLP $1424^{1}$ & - & - & 138.0 & 88.0 & - \\
\hline & MLP $2465^{1}$ & - & - & - & 75.0 & - \\
\hline & FUMDHAM $2673^{2}$ & 87.5 & - & 136.0 & - & - \\
\hline \multirow[t]{2}{*}{ Xenorhinotherium bahiense } & MNRJ 180-V 1 & - & - & 124.0 & 67.0 & - \\
\hline & MNRJ $181-\mathrm{V}^{1}$ & - & - & 120.0 & 57.0 & - \\
\hline
\end{tabular}


Table 6. Measurements of astragali of Macraucheniidae. Abbreviations: DC, distance between the two crests; DDH, dorsoplantar diameter of the head; DDL, dorsoplantar diameter of the lateral face; DDM, dorsoplantar diameter of the medial face; L, length; LL, length of the lateral face; LM, length of the medial face; LMd, length of the middle portion (between the two crests); MD, mediolateral diameter; MDH, mediolateral diameter of the head. ${ }^{1}$ from Vidal (1955), ${ }^{2}$ Guérin \& Faure (2004).

\begin{tabular}{|c|c|c|c|c|c|c|c|c|c|c|c|}
\hline Taxon & $\begin{array}{l}\text { Specimen } \\
\text { Number }\end{array}$ & DC & $\mathrm{DDH}$ & DDL & DDM & $\mathrm{L}$ & $\mathrm{LL}$ & LM & LMd & MD & $\mathrm{MDH}$ \\
\hline \multirow{10}{*}{$\begin{array}{l}\text { Macrauchenia } \\
\text { patachonica }\end{array}$} & MCN-PV 7283 & 46.4 & $33.7^{*}$ & $36.8^{*}$ & $47.9^{*}$ & 87.8 & 85.5 & 85.1 & 74.1 & 70.7 & 53.0 \\
\hline & MCN-PV 8083 & 49.0 & $33.0^{*}$ & $35.5^{*}$ & 42.7 & 94.2 & 89.6 & 89.0 & 75.9 & 72.6 & 52.9 \\
\hline & UFSM 11184 & 46.6 & 33.6 & - & 48.8 & - & - & 72.5 & 62.3 & 61.6 & 49.4 \\
\hline & MLP $2503^{1}$ & - & 51.0 & 57.0 & - & 99.0 & - & - & - & 83.0 & 61.0 \\
\hline & MLP $2504^{1}$ & - & 51.0 & 64.0 & - & 89.0 & - & - & - & 75.0 & 60.0 \\
\hline & MLP $2347^{1}$ & - & 45.0 & 52.0 & - & 80.0 & - & - & - & 69.0 & 55.0 \\
\hline & MLP $2465^{1}$ & - & 53.0 & 62.0 & - & 91.0 & - & - & - & 73.0 & 61.0 \\
\hline & $\begin{array}{l}\text { FUMDHAM } \\
48901^{2}\end{array}$ & $62.0^{*}$ & 41.0 & 35.5 & 55.5 & 81.0 & 79.5 & 78.5 & 66.5 & 67.0 & 51.5 \\
\hline & $\begin{array}{l}\text { FUMDHAM } \\
1648^{2}\end{array}$ & 59.5 & $38.0^{*}$ & 38.0 & - & 80.0 & 81.0 & 81.0 & 67.0 & $64.0^{*}$ & $47.0^{*}$ \\
\hline & $\begin{array}{l}\text { FUMDHAM } \\
7955^{2}\end{array}$ & - & - & - & - & 78.0 & - & 78.0 & 67.0 & - & - \\
\hline $\begin{array}{l}\text { Xenorhinotherium } \\
\text { bahiense }\end{array}$ & MNRJ 09- ${ }^{1}$ & - & 45.0 & 59.0 & - & 86.0 & - & - & - & 69.0 & 57.0 \\
\hline
\end{tabular}

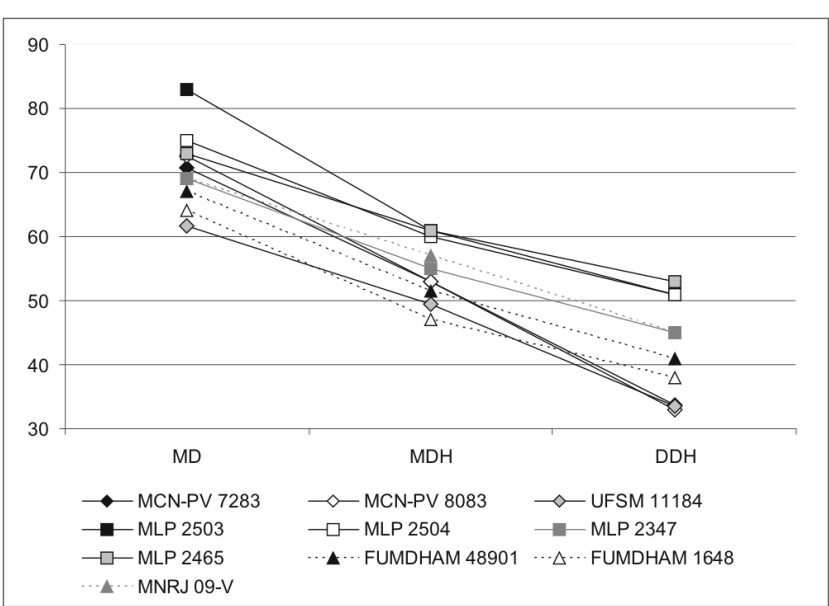

Figure 8. Line graph comparing the measurements of mediolateral diameter (MD), mediolateral diameter of the head $(\mathrm{MDH})$ and dorsoplantar diameter of the head (DDH) of the astragali of Macrauchenia patachonica (MCN-PV 7283, 8083, UFSM 11184, MLP 2503, 2504, 2347, 2465, FUMDAHM 48901, 1648) and Xenorhinotherium bahiense (MNRJ 09-V).

(1988), has measurements very similar to the variation observed for Macrauchenia patachonica. Thus, it is possible to conclude that the astragalus, like other postcranial elements, does not show a size pattern that permit the Macraucheniidae material from Argentina and southern Brazil to be distinguished from that of northeastern Brazil representing Macrauchenia patachonica and Xenorhinotherium bahiense respectively. More complete material could contribute to the differentiation between these forms.

The identification of MCN-PV 1476 (reported by Scherer et al., 2006) as Macrauchenia patachonica was mainly based on the description of a metatarsal II by Guérin \& Faure (2004) and on the fractured metatarsal described and figured by Owen (1838). Relative to size, MCN-PV 1476 is longer, about $195 \mathrm{~mm}$, compared to the Piauí specimens, where the longest specimen is only $188 \mathrm{~mm}$. Therefore, it is possible to conclude that the Rio Grande do Sul metatarsal is slightly larger than the material from São Raimundo Nonato, studied by Guérin
\& Faure (2004). This observation suggests that the proposition of Cartelle \& Lessa (1988) could be acceptable, because they considered that the metapodials of Macrauchenia patachonica are more robust than those from northeastern Brazil, attributing them to $X$. bahiense.

The dentary shows conclusive characters that permit to assign to Macrauchenia patachonica. However, the postcranial elements did not present any diagnostic characters to be assigned to this species. Since the material from Rio Grande do Sul State is late Pleistocene, from which the only known species is Macrauchenia patachonica, and due to the geographic location, the postcranial elements are here tentatively attributed to that species. Still, previous works (e.g., Lessa \& Cartelle, 1988, Lessa \& Cartelle, 1995) considered that there is no difference in the postcranial skeleton between these two species.

\section{FINAL CONSIDERATIONS}

Here, is described and confirmed the presence of the Proterotheriidae in the Pleistocene from Rio Grande do Sul State. This record was based on an astragalus and calcaneum, tentatively assigned to cf. Neolicaphrium recens, the only species of the family known for the Pleistocene. The hind limb elements of this species are unknown, but the size of the studied specimens is very small (similar to forms of Thoatherium and Epecuenia) like the other cranial and mandibular specimens already known for $N$. recens. These finds add a new record of Proterotheriidae confined to a restricted latitudinal belt in the Pleistocene of South America.

The finds of the Macraucheniidae from Rio Grande do Sul State are scarce and incomplete; being almost only postcranial specimens, and therefore, their identification is difficult, since the cranial and dental material provide the most diagnostic characters at a particular level. The Rio Grande do Sul specimens here were assigned to Macrauchenia patachonica, because the mandible fragment and the most postcranial studied specimens are similar in size and morphology to that from Argentina pertaining to this species. 
The comparisons and graphic analysis carried out here indicated, as referred to by Cartelle \& Lessa (1988), that there are few postcranial differences between the material from northeastern Brazil (that could pertain totally to X. bahiense) and that of Macrauchenia patachonica from Argentina.

We believe it is necessary to restudy the material referred to by Guérin \& Faure (2004) to determine whether the material from Piauí State truly pertains to Macrauchenia patachonica, since the latitudinal position, characters and size of the material (see discussion above) indicate that they could pertain to another species of the Macraucheniidae. The record of Macrauchenia patachonica for Rio Grande do Sul is in accordance with the biogeographic segregation proposed by Cartelle \& Lessa (1988) that this species had an austral distribution, from Bolivia to southern Chile, whereas $X$. bahiense occurred in the intertropical region, in northeastern Brazil and Venezuela.

\section{ACKNOWLEDGMENTS}

The authors thank Dr. M. Ubilla for the information and bibliographies, Dr. A.A. da Rosa for access to a studied specimen, Dr. B. Ferrero for the information about the material from Entre Rios Province, Dr. M. Reguero (MLP) for access to the Proterotheriidae holotypes, Dr. J. Ferigolo and the referees who helped improve the manuscript with useful comments, and Conselho Nacional de Desenvolvimento Científico e Tecnológico (CNPq) for financial support (Universal 474485/2008-0).

\section{REFERENCES}

Alvarez, E.H.E.F. de. 1943. Descripción de la Macrauchenia patachonica Owen y comparación con otros géneros terciarios (Theosodon, Scalabrinitherium y Promacrauchenia). Publicaciones de la Facultad de Ciencias Exactas, Físicas y Naturales, Serie B, 19:1-145.

Alvarez, B.B. 1974. Los mamíferos fósiles del Cuaternario de Arroyo Toropí, Corrientes. Ameghiniana, 11(3):295-311.

Ameghino, F. 1888. Rápidas diagnosis de algunos mamíferos fósiles nuevos de la República Argentina. In: A.J. Torcelli (ed.) Obras Completas y Correspondencia Científica de Florentino Ameghino. vol. 5. Taller de Impresiones Oficiales, p. 471-480.

Ameghino, F. 1889. Contribución al conocimiento de los mamíferos fósiles de la República Argentina. Actas de la Academia Nacional de Ciencias de Córdoba, 6:1-1027.

Bergqvist, L.P. 1993. Jazimentos pleistocênicos do estado da Paraíba e seus fósseis. Revista Nordestina de Biologia, 8(2):143-158.

Bergqvist, L.P. 1996. Reassociação do pós-crânio às espécies de ungulados da Bacia de S. J. de Itaboraí (Paleoceno), Estado do Rio de Janeiro, e filogenia dos "Condilarthra" e ungulados sul-americanos com base no pós-crânio. Programa de PósGraduação em Geociências, Universidade Federal do Rio Grande do Sul, PhD Thesis, 406 p.

Bergqvist, L.P.; Gomide, M.; Cartelle, C. \& Capilla, R. 1997. Faunas-locais de mamíferos pleistocênicos de Itapipoca/Ceará, Taperoá/Paraíba e Campina Grande/Paraíba. Estudo comparativo, biostratinômico e paleoambiental. Revista da Universidade de Guarulhos, Geociências, 2(6):23-32.
Bergqvist, L.P.; Ribeiro, A.M. \& Bocquentin-Villanueva, J. 1998. Primatas, Roedores e Litopternas do Mio/Plioceno da Amazônia Sul-Ocidental (Formação Solimões, Bacia do Acre), Brasil. Geologia Colombiana, 23:19-29.

Bombin, M. 1976. Modelo paleoecológico evolutivo para o Neoquaternário da região da Campanha-Oeste do Rio Grande do Sul (Brasil). A Formação Touro Passo, seu conteúdo fossilífero e a pedogênese pós-deposicional. Comunicações do Museu de Ciências da PUCRS, 15:1-90.

Bond, M. 1999. Quatenary native ungulates of Southern South America. A synthesis. In: J. Rabassa \& M. Salemme (eds.) Quaternary of South America and Antarctic Peninsula, A.A. Balkema Publishers, p. 177-205.

Bond, M.; Cerdeño, E. \& López, G. 1995. Los ungulados natives de América del Sur. In: M.T. Alberdi; G. Leone \& E.P. Tonni (eds.) Evolución biológica y climática de la región Pampeana durante los últimos cinco millones de años. Un ensayo de correlación con el Mediterráneo occidental, Monografías del Museo Nacional de Ciencias Naturales, CSIC, p. 259-275.

Bond, M.; Perea, D.; Ubilla, M. \& Tauber, A.A. 2001. Neolicaphrium recens Frenguelli, 1921, the only surviving Proterotheriidae (Litopterna, Mammalia) into the South American Pleistocene. Palaeovertebrata, 30(1-2):37-50.

Buchmann, F.S.C. 1994. Distribuição de fósseis pleistocênicos na zona costeira e plataforma continental interna no Rio Grande do Sul. Acta Geologica Leopoldensia, 17(39/1):355-364.

Buchmann, F.S.C. 2002. Bioclastos de organismos terrestres $e$ marinhos na praia e plataforma interna do Rio Grande do Sul: natureza, distribuição, origem e significado geológico. Programa de Pós-Graduação em Geociências, Universidade Federal do Rio Grande do Sul, PhD Thesis, 108 p.

Burmeister, H. 1864. Descripción de la Macrauchenia patachonica. Anales del Museo Público de Buenos Aires, 1:32-66.

Cabrera, A. 1939. Sobre vertebrados fósiles del Plioceno de Adolfo Alsina. Revista del Museo de La Plata, 2:3-35.

Cartelle, C. \& Lessa, G. 1988. Descrição de um novo gênero e espécie de Macraucheniidae (Mamalia, Litopterna) do Pleistoceno do Brasil. Paula-Coutiana, 3:3-26.

Casamiquela, R. 1999. The Pleistocene vertebrate record of Chile. In: J. Rabassa \& M. Salemme (eds.) Quaternary of South America and Antarctic Peninsula. A.A. Balkema Publishers, p. 91-107.

Cifelli, R.L. \& Guerrero, J. 1997. Litopterns. In: R.F. Kay; R.H. Madden; R.L. Cifelli \& J.J. Flynn (eds.) Vertebrate Paleontology in the Neotropics: the Miocene Fauna of La Venta, Colombia. Smithsonian Institution Press, p. 289-302.

Cione, A.L. \& Tonni, E.P. 2005. Bioestratigrafía basada em mamíferos del Cenozóico Superior de la Província de Buenos Aires, Argentina. In: R.E. Barrio; R.O. Etcheverry; M.F. Caballé \& E. Llambias (eds.) Geología y recursos Minerales de la Província de Buenos Aires, Quick Press, p. 183-200.

Coltorti, M.; Abbazzi, L.; Ferretti, M. P.; Iacumin, P.; ParedesRios, F.; Pellegrini, M; Pieruccini, P.; Rustioni, M.; Tito, G \& Rook, L. 2007. Last Glacial mammals in South America: a new scenario from Tarija (Bolivia). Naturwissenschaften, 94:288299.

Croft, D.A.; Flynn, J.J. \& Wyss, A.R. 2004. Notoungulata and Litopterna of the early Miocene Chucal Fauna, northern Chile. Fieldiana: Geology (New Series), 50:1-52.

Croft, D.A.; Flynn, J.J. \& Wyss, A.R. 2007. A new basal glyptodontid and other Xenarthra of the early Miocene Chucal Fauna, northern Chile. Journal of Vertebrate Paleontology, 27:781-797. 
Da-Rosa, A.A.S. 2003. Preliminary correlation of fluvial deposits at the extreme west of Rio Grande do Sul State, Southern Brazil. In: LATINAMERICAN CONGRESS OF SEDIMENTOLOGY, 3, 2003. Abstracts, Belém, p. 243-245.

Dias-Neto, C.M.; Born, P.A. \& Chahud, A. 2008. Ocorrência de mamíferos extintos do Pleistoceno na localidade de Lagoa da Pedra, Município de Igaci, Alagoas. Revista da Universidade de Guarulhos, Geociências, 7(1):110-115.

Ferrero, B.2009. Mamíferos del Cuaternario de la provincia de Entre Ríos, Argentina: diversidad y evolución. Aspectos bioestratigráficos y paleozoogeográficos de una fauna particular. Facultad de Ciencias Naturales y Museo, Universidad Nacional de La Plata, PhD Thesis, 425 p.

Ferrero, B.; Brandoni, D.; Noriega, J. \& Carlini, A. 2007. Mamíferos de la Formación El Palmar (Pleistoceno tardío) de la provincia de Entre Ríos, Argentina. Revista del Museo Argentino de Ciencias Naturales, 9(2):109-117.

Flynn, J.J.; Novacek, M.J.; Dodson, H.E.; Frassinetti, D.; McKenna, C.; Norell, M.A.; Sears, K.E.; Swisher, C.C. \& Wyss, A.R. 2002. A new fossil mammal assemblage from the southern Chilean Andes: implications for geology, geochronology and tectonics. Journal of South American Earth Sciences, 15:285302.

Flynn, J.J. \& Swisher, C. 1995. Cenozoic South American land mammal ages: correlation to global geochronologies. In: W.A. Berggren; D.V. Kent; M.P. Aubry \& J. Hardenbol (eds.) Geochronology, Time Scales, and Global Stratigraphic Correlation, Society of Sedimentary Geology, p. 317-333.

Frailey, C.D. 1986. Late Miocene and Holocene Mammals, exclusive of the Notoungulata, of the Rio Acre region, Western Amazonia. Contributions in Science, 374:1-46.

Guérin, C. \& Faure, M. 2004. Macrauchenia patachonica Owen (Mammalia, Litopterna) de la région de São Raimundo Nonato (Piauí, Nordeste brésilien) et la diversité del Macraucheiidae pléistocènes. Geobios, 37:516-535.

Kotzian, C.B.; Simões M.G.; Da-Rosa, A.A.S. \& Milder, S.E.S. 2005. AMS Radiocarbon dating of freshwater mollusk shells from the Touro Passo Formation (Pleistocene-Holocene), RS, Brazil. In: CONGRESSO BRASILEIRO DE PALEONTOLOGIA, 19, CONGRESSO LATINO-AMERICANO DE PALEONTOLOGIA, 6, 2005. Resumos, Aracaju, UFS, CD-Rom.

Kramarz, A. \& Bond, M. 2005. Los Litopterna (Mammalia) de la Formación Pinturas, Mioceno temprano-medio de Patagonia. Ameghiniana, 42(3):611-626.

Lessa, G. \& Cartelle, C. 1995. Caracterização Vertebral de Xenorhinotherium bahiense (Liptoterna, Mammalia) do Pleistoceno do Brasil. Acta Geológica Lilloana, 18(1):165-166.

Lessa, G. \& Oliveira, E.V. 1996. Occurrence of Macraucheniids in the Quaternary of Southern, Southeastern and Notheastern regions of Brazil. Ameghiniana, 33(4):466.

Lopes, R.P.; Buchmann, F.S.C.; Caron, F. \& Itusarry, M.E. 2001. Tafonomia dos fósseis de vertebrados (megafauna extinta) encontrados nas barrancas do Arroio Chuí e linha de costa, Rio Grande do Sul, Brasil. Pesquisas em Geociências, 28(2):67-73.

Lopes, R.P.; Buchmann, F.S.C.; Caron, F. \& Itusarry, M.E.G.S. 2005. Barrancas fossilíferas do Arroio Chuí, RS. Importante megafauna pleistocênica no extremo sul do Brasil. In: M. Winge; C. Schobbenhaus; M. Berbert-Born; E.T. Queiroz; D.A. Campos; C.R.G. Souza \& A.C.S. Fernandes (eds.) Sítios Geológicos e Paleontológicos do Brasil. Available in: http://www.unb.br/ ig/sigep/sitio119/sitio119.pdf
López, P.M. \& Labarca, R.E. 2005. Macrauchenia (Litopterna), Hippidion (Perissodactyla), Camelidae y Edentata en Calama (II Región): comentarios taxonómicos y tafonómicos. Noticiario Mensual del Museo Nacional de Historia Natural, 355:7-10.

MacFadden, B.J. \& Shockey, B.J. 1997. Ancient feeding ecology and niche differentiation of Pleistocene Mammalian herbivores from Tarija, Bolivia: morphological and isotopic evidence. Paleobiology, 23(1):77-100.

Marshall, L.G. \& Sempere, T. 1991. The Eocene to Pleistocene vertebrates of Bolivia and their stratigraphic context: a review. Revista Técnica de Yacimientos Petroliferos Fiscales Bolivianos, 12(3/4):631-652.

Marshall, L.G.; Hoffstetter, R. \& Pascual, R. 1983. Mammals and stratigraphy: geochronology of the continental mammal-bearing Tertiary of South America. Palaeovertebrata, Mémoire Extraordinaire:1-93.

Marshall, L.G.; Berta, A.; Hoffstetter, R.; Pascual, R.; Reig, O.A.; Bombin, M. \& Mones, A. 1984. Mammals and Stratigraphy: geochronology of the continental mammal-bearing Quaternary of South America. Palaeovertebrata, Mémoire Extraordinaire:1-76.

Mckenna, M.C. \& Bell, S.K. 1997. Classification of mammals above the species level. New York, Columbia University Press, $631 \mathrm{p}$.

Milder, S.E.S. 2000. Arqueologia do Sudeste do Rio Grande do Sul: uma perspectiva geoarqueológica. Museu de Arqueologia e Etnologia, Universidade de São Paulo, PhD Thesis, 172 p.

Miller, E.T. 1987. Pesquisas arqueológicas paleoindígenas no Brasil Ocidental. Estúdios Atacameños, 8:37-61.

Oliveira, E.V. 1992. Mamíferos fósseis do Quaternário do Estado do Rio Grande do Sul, Brasil. Programa de Pós-graduação em Geociências, Universidade Federal do Rio Grande do Sul, M.Sc. Thesis, $118 \mathrm{p}$.

Oliveira, E.V. \& Lavina, E.L. 2000. Mamíferos: protagonistas dos tempos modernos. In: M. Holz \& L.F. De Ros (eds.) Paleontologia do Rio Grande do Sul, CIGO/UFRGS, p. 376394.

Oliveira, E.V.; Prevosti, F.J. \& Pereira, J.C. 2005. Protocyon troglodytes (Lund) (Mammalia, Carnivora) in the Late Pleistocene of Rio Grande do Sul and their paleoecological significance. Revista Brasileira de Paleontologia, 8(3):215-220.

Oliveira, L.D.D.; Damasceno, J.M.; Lins, F.A.P.L.; Medeiros, W.E. \& Moreira, J.A. 1989. Estudo macrofossilífero dos tanques da fazenda Capim Grosso, São Rafael, RN, auxiliado por métodos geofísicos. In: CONGRESSO BRASILEIRO DE PALEONTOLOGIA, 11, 1989. Anais, Curitiba, UFPR, p. 551570.

Owen, R. 1838. Fossil Mammalia. In: C. Darwin (ed.) The Zoology of the voyage of H. M. S. Beagle, Smith, Elder and Co. p. 1-111.

Pascual, R.; Cattoi, J.C.; Francis, D.; Gondar, E.; Ortega-Hinojosa, R.; Pisano, J.A.; Ringuelet, A.B.; Tonni, E. \& Zetti, J. 1966. Paleontografia Bonaerense IV-Vertebrata. Buenos Aires, Comisión de Investigación Científica, 202 p.

Paula-Couto, C. 1945. Sobre um Macrauquénido gigante, Macraucheniopsis gen. nov. del Pampeano inferior de la Argentina. Notas del Museo de La Plata, 84:233-257.

Paula-Couto, C. 1947. Sobre a presença de Macrauchenia Owen, 1838, no Estado da Bahia. Notas Preliminares e Estudos, Divisão de Geologia e Mineralogia, 45:1-7.

Paula-Couto, C. 1954. Sobre alguns mamíferos fósseis do Ceará. Arquivos do Museu Nacional, 42:195-210.

Paula-Couto, C. 1970. Paleontologia da região de Lagoa Santa, Minas Gerais, Brasil. Boletim do Museu de História Natural UFMG, 1:1-21. 
Paula-Couto, C. 1980. Fossil Pleistocene to Sub-Recent mammals from Northeastern Brazil. I- Edentata Megalonychidae. Anais da Academia Brasileira de Ciências, 52(1):143-151.

Perea, D.; Ubilla, M. \& Bond, M. 1998. The Proterotheriidae (Litopterna), surviving Ungulates in the Pleistocene. Acta Geologica Lilloana, 18(1):176.

Perea, D.; Ubilla, M.; Martinez, S.; Piñero, G. \& Verde, M. 1994. Mamíferos neógenos del Uruguay: la Edad Mamífero Huayqueriense e al "Mesopotamiense". Acta Geologica Leopoldensia, 17(39/1):375-389.

Pitana, V.G.; Scherer, C.S. \& Ribeiro, A.M. 2005. Um Proterotheriidae (Mammalia, Litopterna) no Quaternário do Estado do Rio Grande do Sul, Brasil. In: CONGRESSO LATINO-AMERICANO DE PALEONTOLOGIA DE VERTEBRADOS, 2, 2005. Boletim de Resumos, Rio de Janeiro, MN, p. 205-206.

Ribeiro, A.M. \& Scherer, C.S. Mamíferos do Pleistoceno do Rio Grande do Sul, Brasil. In: A.M. Ribeiro; S.G. Bauermann \& C.S. Scherer (eds.) Quaternário do Rio Grande do Sul: integrando conhecimentos, SBP, in press.

Schaller, O. 1992. Illustrated Veterinary Anatomical Nomenclature. Stuttgart, Enke, 614 p.

Scherer, C.S. \& Da-Rosa, A.A.S. 2003. Um eqüídeo fóssil do Pleistoceno de Alegrete, RS, Brasil. Pesquisas em Geociências, 3(2):33-38.

Scherer, C.S.; Da-Rosa, A.A.S.; Witeck-Neto, L. \& Ubilla, M. 2002. Estudo da megafauna pleistocênica (Edentata e Ungulata) de Pantano Grande, RS. Paleontologia em Destaque, 17:41.

Scherer, C.S.; Da-Rosa, A.A.S.; Witeck-Neto, L.; Ubilla, M. 2003. Contribuição ao estudo da megafauna pleistocênica (Xenarthra, Litopterna, Notoungulata, Proboscidea, Perissodactyla) do Município de Pantano Grande no Estado do Rio Grande do Sul, Brasil. In: JORNADA ACADÊMICA INTEGRADA, 18, 2003. Resumos, Santa Maria, UFSM, CD-Rom.

Scherer, C.S.; Pitana, V.G. \& Ribeiro, A.M. 2006. Os Macraucheniidae (Mammalia, Litopterna) no Quaternário do Rio Grande do Sul, Brasil. Revista Ciência e Natura, Edição Especial:73.

Scott, W.B. 1910. Mammalia of the Santa Cruz Beds. Reports of the Princeton University Expeditions to Patagonia, Vol. 7 Paleontology, 4:1-158.

Sefve, I., 1925. Macrauchenia patagonica (sic). Bulletin of the Geological Institution of the University of Upsala, 19:1-21.

Sisson, S. \& Grossman, J.D. 1963. Anatomia de los Animales Domésticos. $4^{\mathrm{a}}$ ed. Barcelona, Salvat, $952 \mathrm{p}$.
Socorro, O.A.A. 2006. Tesoros paleontológicos de Venezuela, el Cuaternario del Estado Falcón. Taima Taima, Instituto del Patrimonio Cultural, $120 \mathrm{p}$.

Soria, M.F. 2001. Los Proterotheriidae (Mammalia, Litopterna): sistemática, origen y filogenia. Monografías del Museo Argentino de Ciencias Naturales, 1:1-167.

Souza-Cunha, F.L. 1959. Mamíferos fósseis do Pleistoceno do Rio Grande do Sul. I-Ungulados. Rio de Janeiro, Departamento Nacional da Produção Mineral, Divisão de Geologia e Mineralogia, 47 p. (Boletim 202).

Tauber, A.A. 2000. Hallazgos de Proterotheriidae (Mammalia, Litopterna) en el Pleistoceno de Córdoba, Argentina. Ameghiniana, 37(2):157-162.

Tomazelli, L.J. \& Villwock, J.A. 2000. O Cenozóico do Rio Grande do sul: geologia da planície costeira. In: M. Holz \& L.F. De Ros (eds.) Geologia do Rio Grande do Sul, CIGO-UFRGS, p. 375406.

Ubilla, M. 2004. Mammalian biostratigraphy of Pleistocene fluvial deposits in Northern Uruguay, South America. Proceedings of the Geologists' Association, 115:347-357.

Ubilla, M.; Perea, D. \& Martinez, S. 1994. Paleofauna del Cuaternario Tardio Continental del Uruguay (Fm. Sopas y Fm. Dolores) Acta Geologica Leopoldensia, 17(39/1):441-458.

Ubilla, M.; Perea, D.; Rinderknecht, S. \& Bond, M. 2007. Primeros resgistros de restos craneanos de Proterotéridos (Litopterna) del Peistoceno. In: CONGRESO URUGUAYO DE GEOLOGÍA, 5, 2007. Resúmenes, Montevideo, SUG, p. 89.

Vezzosi, R.I.; Schimidt, G.I. \& Brunetto, E. 2009. Un Proterotheriinae (Proterotheriidae: Litopterna) en el Pleistoceno tardío-Holoceno temprano (Lujanense) de Santa Fe. In: JORNADAS ARGENTINAS DE PALEONTOLOGÍA DE VERTEBRADOS, 24, 2009. Libro de Resúmenes, San Rafael, p. 62.

Vidal, N. 1946. Contribuição ao conhecimento da paleontologia do nordeste brasileiro. Boletim do Museu Nacional, Série Geologia, 6:1-15.

Vidal, N. 1955. Estudo descritivo e comparativo de Macrauchenia patachonica Owen de Pernambuco. Boletim do Museu Nacional, Série Geologia, 21:1-39.

Villwock, J.A. \& Tomazelli, L.J. 1995. Geologia Costeira do Rio Grande do Sul. Notas Técnicas, 8:1-45.

Winge, H. 1906. Jordgundne og nulevende Hovdyr (Ungulata) fra Lagoa Santa, Minas Gerais, Brasilien. Med udsigt over gumlernes indbyrdes slaegtskab. E Museo Lundii, 3(1):1-239.

Received in September, 2009; accepted in November, 2009. 